\title{
Creating a Safety Culture
}

Michelle A. Dolfini-Reed

Burton L. Streicher

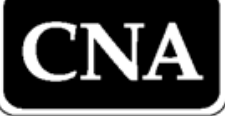

4825 Mark Center Drive • Alexandria, Virginia 22311-1850 


\section{Report Documentation Page}

Form Approved OMB No. 0704-0188

Public reporting burden for the collection of information is estimated to average 1 hour per response, including the time for reviewing instructions, searching existing data sources, gathering and maintaining the data needed, and completing and reviewing the collection of information. Send comments regarding this burden estimate or any other aspect of this collection of information,

including suggestions for reducing this burden, to Washington Headquarters Services, Directorate for Information Operations and Reports, 1215 Jefferson Davis Highway, Suite 1204, Arlington

VA 22202-4302. Respondents should be aware that notwithstanding any other provision of law, no person shall be subject to a penalty for failing to comply with a collection of information if it

does not display a currently valid OMB control number.

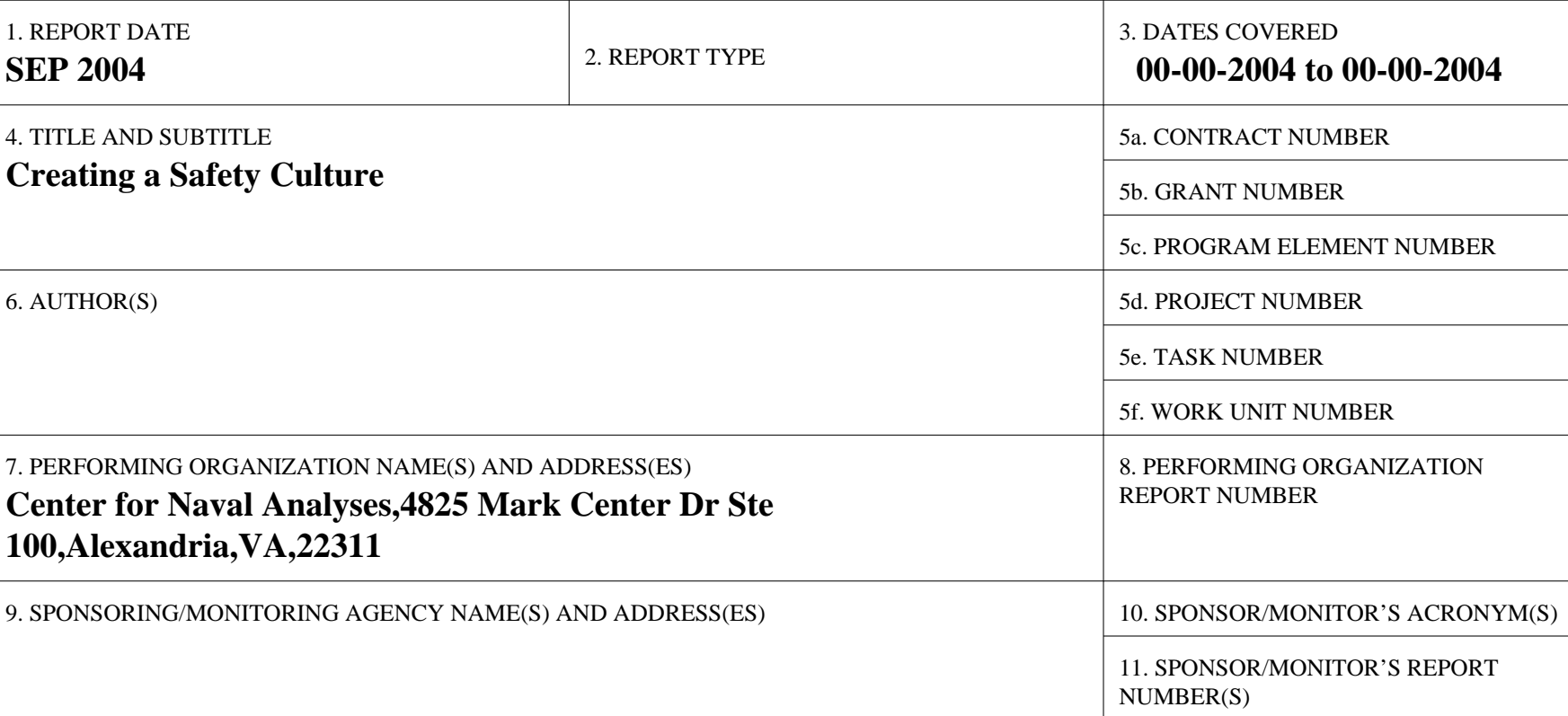

12. DISTRIBUTION/AVAILABILITY STATEMENT

Approved for public release; distribution unlimited

13. SUPPLEMENTARY NOTES

14. ABSTRACT

15. SUBJECT TERMS

16. SECURITY CLASSIFICATION OF:

\begin{tabular}{c|c|c|c|}
$\begin{array}{c}\text { a. REPORT } \\
\text { unclassified }\end{array}$ & $\begin{array}{c}\text { b. ABSTRACT } \\
\text { unclassified }\end{array}$ & $\begin{array}{c}\text { c. THIS PAGE } \\
\text { unclassified }\end{array}$ & $\begin{array}{c}\text { Same as } \\
\text { Report (SAR) }\end{array}$
\end{tabular}

\begin{tabular}{c|l}
$\begin{array}{c}\text { 18. NUMBER } \\
\text { OF PAGES } \\
\mathbf{5 6}\end{array}$ & 19a. NAME OF \\
& \\
&
\end{tabular}

Standard Form 298 (Rev. 8-98) Prescribed by ANSI Std Z39-18 


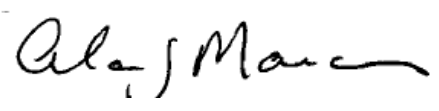

\section{Alan J. Marcus, Director Infrastructure and Readiness Team Resource Analysis Division}

This document represents the best opinion of CNA at the time of issue. It does not necessarily represent the opinion of the Department of the Navy.

Cleared for Public Release; Distribution Unlimited. Specific authority: N00014-00-D-0700.

For copies of this document call: CNA Document Control and Distribution Section at 703-824-2123.

\section{Copyright $\odot 2004$ The CNA Corporation}




\section{Contents}

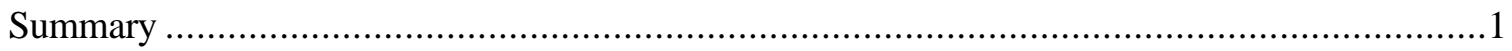

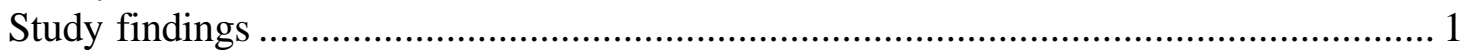

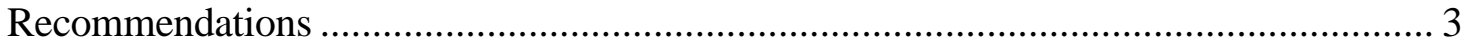

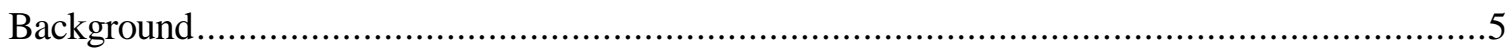

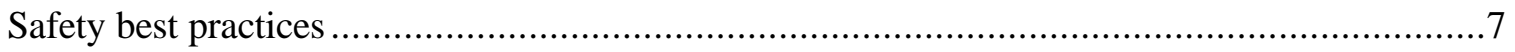

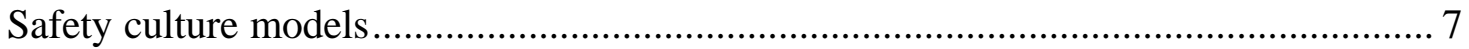

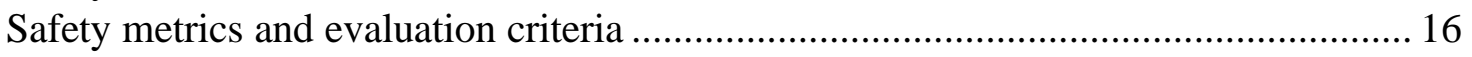

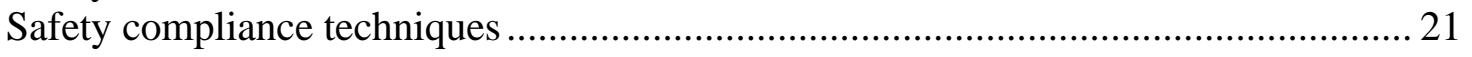

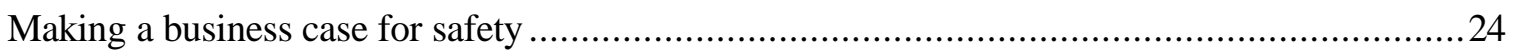

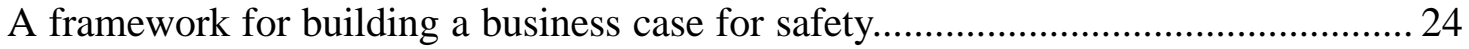

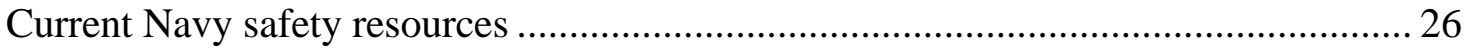

Naval Safety Center .................................................................................. 27

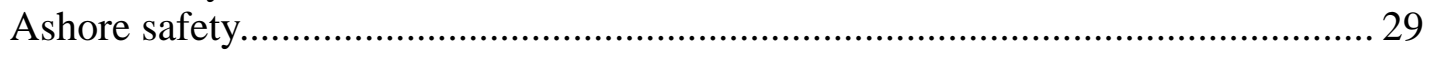

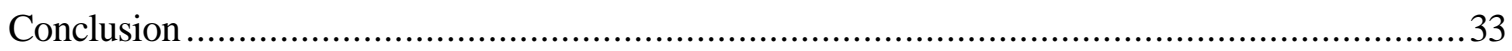

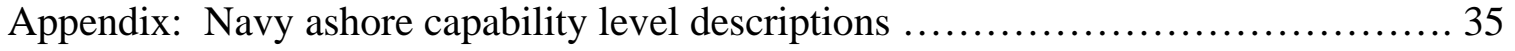

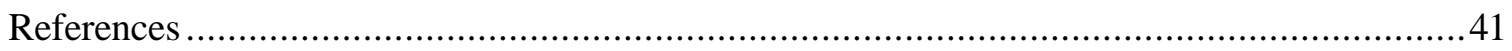

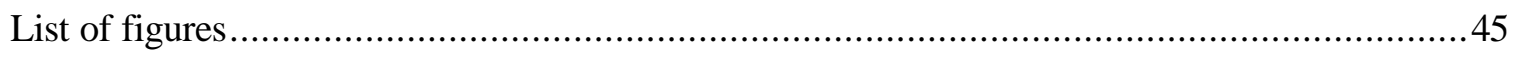

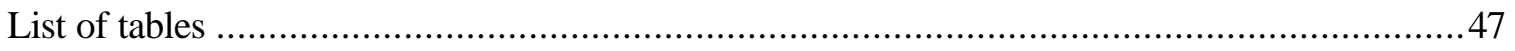

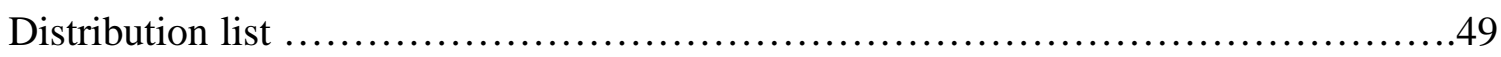




\section{Summary}

Preventable injuries and illnesses present a significant cost to military readiness. The National Safety Council estimates that preventable injuries and illnesses cost DoD $\$ 10$ billion to over $\$ 21$ billion annually [1]. In 2003, to address recent increases in accident rates, the Secretary of Defense challenged the military services to reduce mishap rates by 50 percent over a 2 -year period ending September 2005 [2]. Nearly concurrent in April 2003, the Deputy Assistant Secretary of the Navy for Safety (DASN (Safety)) submitted a report to the Secretary of the Navy in which she recommended improvements to Navy activities supporting safety. The aim was to strengthen the contribution of safety to mission effectiveness and enhance the safety of Sailors, Marines, and civilian employees. Ensuring safety resources was among the topics addressed by the task force. With respect to this topic, the task force recommended that the Navy "develop a safety resources plan to maximize the safety contribution to the Department of the Navy mission and establish guidance on tracking safety costs for ashore, afloat, ground, and aviation activities, using standard fiscal nomenclature [3]."

In leading the Navy's response to the Secretary of Defense's goal, the DASN for Safety is concerned whether the Navy is fostering a culture of safety that supports meeting safety requirements at the activity and operational levels that will, in turn, support the achievement of short term goals and sustain program success over the long-term. She asked CNA to help develop a strategy to foster a culture of safety within the Navy and Marine Corps, including the identification of ways to make a business case for safety.

In this study, we focus on answering the basic question of how best to raise awareness and provide focus that supports excellence in safety Navy-wide and that generates the optimum mishap rate reduction for the funds invested. Specifically, we answer the following questions:

- What practices does industry use to create a culture of safety? What types of metrics do industry leaders use to track and evaluate safety activities and performance? How do they ensure safety compliance?

- Given the Navy's culture, organization, and mission, how can the Navy integrate aspects of private sector safety models and methods to support its safety practices and to make good business decisions about safety?

\section{Study findings}

In this report, we provide our findings regarding strategies for fostering a culture of safety in the Navy and approaches for making a business case for safety. We look at the business practices that private sector companies use to create a culture of safety within their organizations, the types of metrics they use to track and 
evaluate safety activities and performance, and how they enforce program compliance. We also review the Navy's safety culture, organization, and mission to determine whether any of these best practices could be integrated into the Navy's safety program.

We found that industry leaders' approaches to managing safety had the following features in common:

- Define safety as a core business value and do not relegate safety to the status of a priority, process, or program

- Link safety performance to the corporate bottom- line

- Provide top-level management safety leadership

- Promote employee involvement and empowerment

- Conduct regular evaluation and analyses of worksites to identify hazards

- Ensure a rigorous accident reporting system and require local self-inspections

- Provide corporate-wide standards for safety and skill training

- Use both leading and lagging metrics to measure safety results

- Include safety results as part of their budget development and reporting system

In reviewing the Navy's current approach for managing safety, we found that the Navy's safety practices differ from those of industry leaders in the following ways:

- The Navy does not consider safety a core value; it treats safety as one among many programs

- The Navy does not link safety to its "corporate bottom-line"-in this case, personnel readiness

- Navy safety metrics focus on lagging measures (also referred to as downstream results)

- The Navy closely tracks and regularly reports the occurrence of Class A mishaps which, by definition, result in a fatality, the loss of property valued at $\$ 1$ million or more, or the loss of an aircraft rather than regularly reporting on the rate of injuries or lost workdays

- The Navy does not regularly track injuries, illnesses and lost work time for active duty members

- The Navy does not require safety self-audits

- The Navy does not conduct ashore safety compliance inspections

- Safety training for both civilian employees and active duty members is not centrally managed or tracked

- The Navy funds its safety program at capability level 3, which allows it to meet only some of its occupational health and safety requirements.

- The Navy does not know how much each of its major claimants invests in safety prevention and detection activities. It also does not know its total internal and external failure costs. 


\section{Recommendations}

In light of our findings, we suggest that the Navy consider implementing the following recommendations if it wants to emulate industry best practices:

- Provide leadership that encourages and supports the undertaking of safety initiatives.

- Track and regularly report on illness, injuries, and lost work time for active duty members as well as civilian employees.

- Hold Navy leadership, sailors, and civilian employees accountable for their safety performance.

- Pay more attention to Class B and C mishaps by regularly tracking and reporting on the frequency of these mishaps, investigating and analyzing root causes, and developing and implementing risk control and prevention measures.

- Establish a requirement to report personnel readiness status through the chain of command to the secretariat so the impact of injuries can be monitored and managed

- Require Navy commands to conduct annual self-inspection and submit results to the Naval Safety Center

- Establish random periodic safety compliance inspections through an outside independent contractor and require commands to pay for this service and reinspections

- Create an employee lost-time costing category for each command and require rollup and budgeting similar to what is used for supplies, contracting, equipment, etc.

The Naval Safety Center provides a robust safety support program with magazines, training support aids, work-site safety-development materials, publication of best practices, electronic reporting of mishaps, safety "surveys,"1 policy guidance, and statistical information. However, the current Navy culture does not encourage the kind of management leadership and employee involvement that is found in the best industry safety programs. Management's attention is on Class A mishaps, which includes fatalities. The Navy does not regularly track and report rates for the severely injured, those injured sufficiently to cause lost time, and employees losing work time due to occupationally related illnesses. The Navy needs to track lost work time and associated costs due to injury and illness rates on a regular basis. These rates should reflect lost work time for active duty members, federal civilian employees and contractors. Tracking lost work time for all components of its workforce will allow the Navy to better understand the impact (both real and potential) between safety and readiness.

\footnotetext{
${ }^{1}$ The Naval Safety Center's safety surveys essentially provide Navy platforms with an informal safety evaluation. Generally a platform will request a safety survey from the Safety Center shortly before its 3-year assessment by Inspections and Surveys (INSURV).
} 
The Navy can make a business case for safety by conne cting safety to readiness, and there are frameworks that could serve as ready tools for undertaking this task. We describe one approach in this paper built from the quality management literature that the Navy can use to make a business case for safety. The Navy's challenge is identifying the needed cost data in order to use this approach and assessing the impact of safety performance on readiness. We recommend specifically that the Navy undertake further work that evaluates the impact of safety on readiness. 


\section{Background}

Traditionally, the Navy has considered safety to be a support program that competes for funding resources although it is not funded as a separate line item in the Navy's budget. Individual commands are responsible for implementing and executing safety activities. On occasion the Secretary of the Navy or the Chief of Naval Operations identifies safety as a priority item in their respective yearly statements of goals and initiatives. For the Navy, safety is a program, sometimes a priority, but not a core value.

A general review of Navy mishap rates among civilian personnel during the 1990s suggests that the Navy was doing well in reducing mishaps among its civilian workforce. From 1988 to 1998, the Navy experienced roughly a 40-percent reduction in civilian mishap rates. However, a recent CNA study [4] found that nearly half of this improvement is explained by demographic factors associated with the declining size of the Navy's industrial workforce during the period. Much of the remaining improvement can be attributed to a "catch-up" effect achieved by activities that still did not match the average Navy mishap rate in their occupational fields. Furthermore, as of 1998, substantial differences in safety performance remained for similar jobs across Navy commands reflecting widespread differences in program implementation and results. Estimates from [4] indicate that a further 56-precent reduction in overall mishaps was possible if lagging activities improved enough to match the best in class performance among their peers.

In 2001, the National Safety Council, in partnership with the Department of Defense (DoD), assembled a panel of experts from industry, labor, and government to conduct an executive assessment of DoD's safety and occupational health management systems. Its major finding was that DoD lacked an effective department-wide system [1]. They noted: "This deficiency has serious consequences for the Department's mission because preventable injuries and illnesses absorb substantial human and financial resources that are needed for operational readiness." They estimated annual costs range from $\$ 10$ billion to over \$21 billion. Furthermore, the NSC panel found that DoD does not view occupational injury and illness loss as a readiness concern requiring high-level attention and views safety and occupational health as a low priority.

Nearly concurrent with the NSC panel's assessment, the Navy's DASN for Safety officially assumed this newly created position in September 2001 to provide policy, oversight, advocacy and strategic planning for the Navy and Marine Corps Safety, Occupational Health, and Fire Protection programs. Major responsibilities for this office include advocating for safety funding and professional staffing, and encouraging the development and championing of individual Navy and Marine Corps safety initiatives. The DASN for Safety's goal is to elevate safety as a core business and organizational value and to foster a culture of safety that enhances and supports personnel readiness. 


\section{Safety best practices}

Private industry provides numerous examples of best practices in safety. In this section, we discuss a selection of approaches taken by various industry leaders We focus specifically on their safety culture, safety metrics and evaluation criteria, and compliance techniques. We selected eight industry leaders from the Occupational Safety and Health Administration's (OSHA's) list of current Voluntary Protection Program (VPP) ${ }^{2}$ participants who have at least one corporate site that has achieved OSHA's top recognition, earning the grade of "star." These industry leaders are large companies with a worldwide presence; their total number of employees ranges from approximately 32,500 to over 300,000. We also include the U.S. Department of Energy, which created its VPP, modeled upon OSHA's program in 1994. We list our selection of occupational health and safety leaders in table 1.

\section{Safety culture models}

How do industry leaders create and foster a culture of safety in their organizations? In table 2, we list the key elements of industry safety models for DuPont, General Electric, the Department of Energy, Halliburton, and Lockheed Martin. Although no two approaches are exactly alike, we find a number of similarities across the key safety model elements for these industry leaders.

First, they all tend to include the elements of management leadership and employee involvement in their approaches to environmental, health, and safety. Common characteristics include commitment, accountability, defining roles and responsibilities, defining policies and objectives, planning and self-assessment, and annual evaluations. Second, industry leaders tend to include some form of worksite analysis in their standard operating procedures such as baseline hazard analysis of work activities, the identification of routine high-risk operations, accident reporting, and self-inspections. Hazard prevention and control activities are a common function as well. These activities include risk management, chemical management, required use of personal protective equipment, an occupational healthcare program, on-site medical care, an emergency preparedness system, and fire prevention.

\footnotetext{
${ }^{2}$ The VPP is an OSHA cooperative program that promotes safety and health in the workplace. Corporate management, labor, and OSHA form cooperative relationships in workplaces that have implemented comprehensive safety and health management systems. OSHA designation as a member of the VPP is extended only to those organizations that have achieved exemplary occupational safety and health as measured against a set of performance-based criteria [5].
} 
Table 1. Selected industry and government leaders in occupational health and safety

\begin{tabular}{|c|c|c|c|}
\hline Company name & Industry type & $\begin{array}{l}\text { Number of } \\
\text { employees }\end{array}$ & $\begin{array}{l}\text { Number of } \\
\text { Star sites }\end{array}$ \\
\hline Alcoa & $\begin{array}{l}\text { Electric, gas, and sanitary services } \\
\text { Special trade contractors }\end{array}$ & $\begin{array}{c}120,000 \\
(41 \text { countries })\end{array}$ & 3 \\
\hline DuPont & Chemicals and allied products & $\begin{array}{c}77,000 \\
(70+\text { countries })\end{array}$ & 3 \\
\hline GE & $\begin{array}{l}\text { Heavy construction } \\
\text { Chemicals and allied products } \\
\text { Stone, clay, and glass products } \\
\text { Primary metal } \\
\text { Industrial machinery and } \\
\text { equipment } \\
\text { Electronic and other electric } \\
\text { equipment } \\
\text { Transportation equipment } \\
\text { Instruments and related products } \\
\text { Transportation by air } \\
\text { Transportation services } \\
\text { Electric, gas, and sanitary services } \\
\text { Business services } \\
\text { Miscellaneous repair services } \\
\text { Engineering/management services }\end{array}$ & $\begin{array}{c}300,000+ \\
(100+\text { countries })\end{array}$ & 74 \\
\hline Halliburton & $\begin{array}{l}\text { Industrial machinery /equipment } \\
\text { Chemicals and allied products }\end{array}$ & $\begin{array}{c}100,000+ \\
(120+\text { countries })\end{array}$ & 7 \\
\hline Lockheed Martin & $\begin{array}{l}\text { Electronic and other electric } \\
\text { equipment } \\
\text { Transportation equipment } \\
\text { Instruments and related products } \\
\text { Engineering/management services }\end{array}$ & $\begin{array}{c}130,000 \\
\text { worldwide }\end{array}$ & 4 \\
\hline Lucent & $\begin{array}{l}\text { Primary metal } \\
\text { Electronic and other electric } \\
\text { equipment } \\
\text { Engineering/management services }\end{array}$ & $\begin{array}{c}32,500 \\
\text { worldwide }\end{array}$ & 7 \\
\hline Raytheon & $\begin{array}{l}\text { Heavy construction } \\
\text { Business services }\end{array}$ & $\begin{array}{c}78,000 \\
\text { worldwide }\end{array}$ & 2 \\
\hline Weyerhaeuser & $\begin{array}{l}\text { Lumber and wood products } \\
\text { Paper and allied products } \\
\text { Wholesale trade durable goods }\end{array}$ & $\begin{array}{c}55,200 \\
(18 \text { countries })\end{array}$ & 9 \\
\hline $\begin{array}{l}\text { U.S. Department of } \\
\text { Energy }\end{array}$ & National security & $\begin{array}{c}11,000 \text { federal } \\
126,000 \text { contract }\end{array}$ & 19 \\
\hline
\end{tabular}


Table 2. Key elements of industry leaders' safety models

\begin{tabular}{|c|c|c|c|c|c|}
\hline $\begin{array}{c}\text { Key } \\
\text { Elements }\end{array}$ & DuPont & General Electric & $\begin{array}{c}\text { Department of } \\
\text { Energy }\end{array}$ & Halliburton & $\begin{array}{c}\text { Lockheed } \\
\text { Martin }\end{array}$ \\
\hline $\begin{array}{l}\text { Management } \\
\text { leadership } \\
\text { and } \\
\text { Employee } \\
\text { Involvement }\end{array}$ & $\begin{array}{l}\text { Management } \\
\text { leadership and } \\
\text { accountability } \\
\text { Program } \\
\text { evaluation } \\
\text { Goals and } \\
\text { planning } \\
\text { Employee } \\
\text { involvement } \\
\text { and } \\
\text { responsibility } \\
\text { Off-the-job } \\
\text { safety } \\
\text { Safety is a } \\
\text { core value } \\
\text { integrated } \\
\text { across } \\
\text { business } \\
\text { functions }\end{array}$ & $\begin{array}{l}\text { Site health and } \\
\text { safety plan } \\
\text { Expectations and } \\
\text { performance } \\
\text { appraisal } \\
\text { Program } \\
\text { evaluation } \\
\text { Employee } \\
\text { involvement } \\
\text { Contractor } \\
\text { health/safety } \\
\text { Motor vehicle } \\
\text { safety }\end{array}$ & $\begin{array}{l}\text { Line } \\
\text { management } \\
\text { responsibility } \\
\text { for safety } \\
\text { Defined safety } \\
\text { policy } \\
\text { Established } \\
\text { clear roles and } \\
\text { responsibil- } \\
\text { ities } \\
\text { Balance } \\
\text { priorities, } \\
\text { allocate } \\
\text { resources }\end{array}$ & $\begin{array}{l}\text { Leadership } \\
\text { and } \\
\text { commitment } \\
\text { Policy and } \\
\text { strategic } \\
\text { objectives } \\
\text { Organization, } \\
\text { resources, and } \\
\text { documenta- } \\
\text { tion } \\
\text { Accountability } \\
\text { Management } \\
\text { systems and } \\
\text { standards } \\
\text { Auditing \& } \\
\text { review }\end{array}$ & $\begin{array}{l}\text { Operating } \\
\text { policies } \\
\text { Commitment } \\
\text { Objectives } \\
\text { Performance } \\
\text { metrics } \\
\text { Foster safety } \\
\text { leaders } \\
\text { Senior } \\
\text { management } \\
\text { review } \\
\text { Integrated } \\
\text { activity }\end{array}$ \\
\hline $\begin{array}{l}\text { Worksite } \\
\text { Analysis }\end{array}$ & $\begin{array}{l}\text { Self- } \\
\text { assessment } \\
\text { and } \\
\text { evaluation } \\
\text { Analysis of } \\
\text { work practices }\end{array}$ & $\begin{array}{l}\text { Accident reporting } \\
\text { Investigation/fol- } \\
\text { low-up } \\
\text { Inspections }\end{array}$ & $\begin{array}{l}\text { Define scope } \\
\text { of work } \\
\text { Analyze } \\
\text { hazards and } \\
\text { develop } \\
\text { controls } \\
\text { Identify safety } \\
\text { standards and } \\
\text { requirements } \\
\text { before work is } \\
\text { performed } \\
\text { Perform work } \\
\text { within hazard } \\
\text { controls }\end{array}$ & $\begin{array}{l}\text { Implementa- } \\
\text { tion and } \\
\text { monitoring }\end{array}$ & Self assessment \\
\hline $\begin{array}{l}\text { Hazard } \\
\text { Prevention } \\
\text { and Control }\end{array}$ & $\begin{array}{l}\text { Hazard } \\
\text { prevention } \\
\text { and controls } \\
\text { Continuous } \\
\text { improvement }\end{array}$ & $\begin{array}{l}\text { Job safety analysis } \\
\text { Identify high risk } \\
\text { operations } \\
\text { Review } \\
\text { new/modified } \\
\text { facilities/equip- } \\
\text { ment }\end{array}$ & $\begin{array}{l}\text { Hazard } \\
\text { controls, } \\
\text { including } \\
\text { administrative } \\
\text { and } \\
\text { engineering } \\
\text { controls, } \\
\text { tailored to } \\
\text { work }\end{array}$ & $\begin{array}{l}\text { Risk } \\
\text { evaluation } \\
\text { and } \\
\text { management } \\
\text { Planning and } \\
\text { continuous } \\
\text { improvement }\end{array}$ & $\begin{array}{l}\text { Risk assessment } \\
\text { Risk } \\
\text { management } \\
\text { Continuous } \\
\text { improvement }\end{array}$ \\
\hline
\end{tabular}




\begin{tabular}{|c|c|c|c|c|c|}
\hline $\begin{array}{c}\text { Key } \\
\text { Elements }\end{array}$ & DuPont & General Electric & $\begin{array}{c}\text { Department of } \\
\text { Energy }\end{array}$ & Halliburton & $\begin{array}{l}\text { Lockheed } \\
\text { Martin }\end{array}$ \\
\hline & & $\begin{array}{l}\text { Personal } \\
\text { protective } \\
\text { equipment } \\
\text { Emergency } \\
\text { preparedness and } \\
\text { fire prevention } \\
\text { Industrial hygiene } \\
\text { program } \\
\text { Chemical } \\
\text { management } \\
\text { Ergonomics } \\
\text { Health/safety } \\
\text { specialist } \\
\text { Medical services } \\
\text { Lock out/tag out }\end{array}$ & $\begin{array}{l}\text { Provide } \\
\text { feedback and } \\
\text { continuous } \\
\text { improvement }\end{array}$ & & \\
\hline Training & $\begin{array}{l}\text { Safety and } \\
\text { health training }\end{array}$ & $\begin{array}{l}\text { Health and safety } \\
\text { training }\end{array}$ & $\begin{array}{l}\text { Competence } \\
\text { commensurate } \\
\text { with } \\
\text { responsibility }\end{array}$ & Training & Training \\
\hline
\end{tabular}


Training is heavily emphasized and encompasses both safety and skill training to ensure that people are able to competently meet their safety responsibilities. Industry leaders consistently achieve excellence in safety performance that goes beyond basic compliance with OSHA rules and regulations. They emphasize the full integration of their safety and health management systems within their corporate business model. Excellence in managing safety is of primary importance in all aspects of their business activities.

In figure 1, we provide an example of how one industry leader has designed its safety model as an integrated part of all business units and their activities. Halliburton's Health, Safety, and Environment (HSE) Architecture situates the HSE function as second only to Halliburton's corporate polices and Code of Business Conduct. The components of HSE management include leadership and commitment, clearly defined policies and strategic objectives, dedication and availability of organizational resources and corporate documentation, continuing risk evaluation and management, planning, implementation and monitoring of hazard control activities, and annual auditing and review of HSE performance.

Figure 1. Halliburton's Health, Safety, and Environment Management Architecture

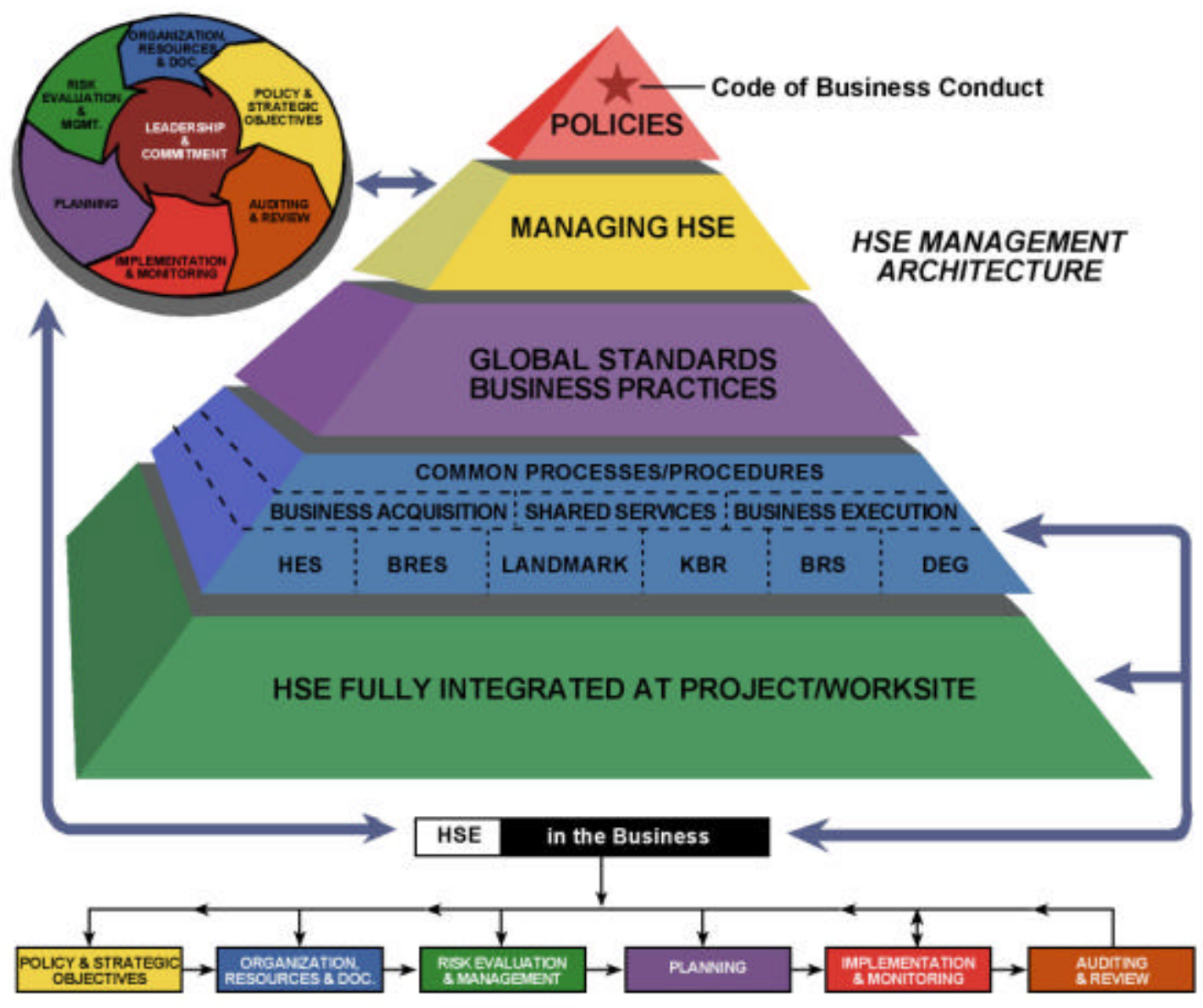


These components are integrated throughout the company's business practices. HSE management fits within the shared services function of Halliburton's business model, but it also affects the business acquisition and business execution functions. Each business unit within Halliburton ${ }^{3}$ is expected to fully incorporate the management of HSE into their processes and procedures and to integrate HSE activities fully at the worksite.

Halliburton's integrated HSE architecture depicts a common approach among industry leaders: in our review of the literature and individual corporate practices, we found that industry leaders consistently note the importance of recognizing and integrating occupational safety and health as a core business and organizational value. Industry safety leaders tend to formally define safety as a core business value that is fully integrated with all work activities. These organizations do not delegate safety to the status of a priority, a process, or a program. It is a value. Core values are constant and remain part of an organization's culture, whereas priorities change. Safety leaders tend to argue in their annual reports and other corporately published occupational health and safety literature that safety and health add value to their businesses, to their respective workplaces, and to the overall quality of their employees' lives. The following are examples of safety industry leaders' corporate statements defining safety as a core value:

Alcoa: "We work safely in a manner that protects and promotes the health and well-being of the individual and the environment....We value human life above all else and manage risks accordingly."

DuPont: "Throughout its history, DuPont has been guided by a welldefined set of core values that have remained constant as DuPont grew from its origins as an explosives' company to the global science company it is today. Safety and health, environmental stewardship, high ethical standards and respectful treatment of people remain the values of DuPont. They are practiced everywhere the company does business. All our operations around the world are held to the same standards."

Halliburton: “...maintains Health, Safety \& Environment (HSE) as a core value and provides support on HSE matters as they relate to our business activities. It is a value that we believe is integral to all of our business objectives."

Raytheon: "....valuing people starts with a healthy and safe work environment."

\footnotetext{
${ }^{3}$ Halliburton's business units are shown in the blue-tiered section of the pyramid depicted in figure 1. From left to right in the figure, they are as follows: HES, Ha lliburton Energy Services; BRES, Brown \& Root Energy Services; Landmark, Landmark Graphics Corporation; KBR, Kellogg Brown \& Root; BRS, Brown \& Root Services; and DEG, Dresser Equipment Group.
} 
Weyerhaeuser: "We are an employer of choice with high-performing people working together in a safe and healthy workplace where diversity, development and teamwork are valued and recognized."

U.S. Department of Energy: "The commonality between all efforts undertaken by the Department of Energy is an unwavering commitment to the protection of our workers, our nation, and the environment. DOE works diligently to ensure that all programs are performed in a safe, healthful, and environmentally sound manner."

By defining safety as a core value, these organizations also broadly include safety as a measure of business success that provides them with a competitive advantage. They directly link achieving excellence in safety performance to their corporate bottom- line. As noted earlier, the National Safety Council executive panel was critical of the military services' failure to include safety in their core values and to recognize the impact of avoidable injuries and illnesses on operational readiness. We conducted interviews with key informants representing various major commands and occupational health and safety professionals within the Navy. We found a general perception among those interviewed that echoes the National Safety Council executive panel's conclusions regarding the military services' attention to safety. The only noted exception was Navy aviation, which many cited as the only component of the Navy that has historically fostered a culture of operational readiness through safety in which safety is integrated throughout its organizational and professional culture.

Although the Navy does not formally include safety in its core values of "Honor, Courage, and Commitment" or point to achieving safety excellence as a measure of success, Navy leadership has taken steps during the past 2 years to elevate safety as an issue receiving attention at the highest levels of the organization. For 2 consecutive years, Department of the Navy yearly objectives have included the goal of reducing safety mishaps. In November 2003, the Secretary of the Navy formally created the Navy and Marine Corps Safety Council ${ }^{4}$ to advise and recommend safety performance improvements to the Chief of Naval Operations, the Commandant of the Marine Corps, and the DASN (Safety).

Safety industry leaders clearly communicate to their managers and employees that they are expected to support and be actively involved in activities supporting continual improvements in occupational health and safety. In November 2003, the Secretary of the Navy released a message to all Navy and Marine Corps commands clearly stating and emphasizing SECNAV safety policy:

\footnotetext{
${ }^{4}$ Council membership is made up of representatives from the Navy afloat, aviation and ashore communities and the Marine Corps.
} 
Every command, every work center, every unit will have a safety culture built on three principles: leadership commitment, leadership courage, and leadership integrity. Today's leaders for safety must exhibit a solid commitment to communicate safety policy and to personally abide by it. They must verbalize a belief in the value of safety and create an environment that encourages open, frank communication. They must have the courage to set and enforce tough and sometimes-unpopular standards, to allocate safety resources (the right people and sufficient funding), and to provide quality training to ensure their personnel learn correct safety practices. Today's leaders must have the integrity to hold themselves and their people accountable for violations of safety standards and to admit their own safety failures so others will do likewise. An effective leader must also openly praise and celebrate safety accomplishments...[6]

The Navy has taken the first necessary step to fostering a safety culture: clearly defining safety policy and expectations. However, although this action is necessary, it is not sufficient to achieve change. Next, Navy leadership must make its safety policy real by translating the words to behavior. The Navy Marine Corps Safety Council should be providing proactive leadership that encourages safety initiatives throughout each military service. As part of its safety and health program qualifications for achieving star recognition in the VPP, OSHA identifies the types of characteristics and activities that organizations must demonstrate through management leadership and employee involvement, which is one of OSHA's four critical elements in the VPP design. We summarize these in table 3 . These activities and behaviors essentially represent ways that an organization's managers can visibly demonstrate to their employees their personal commitment to safety and health protection. Employee involvement connects all members of an organization to safety as a core value. Extending application of the safety and health rules and policies to all on-site contractors and subcontractors further reinforces and fosters the safety culture.

Holding Navy leadership, Sailors, and civilian employees accountable for their safety performance provides a major incentive to everyone to make Navy safety policy a reality through actions and not just written words. Measuring and evaluating performance on a regular basis encourages behavior that fosters a culture of safety. We address safety metrics and evaluation criteria in the next section. 
Table 3. Demonstrating management leadership and employee involvement

\begin{tabular}{|c|c|}
\hline Required characteristic & As demonstrated by.. \\
\hline Management leadership & $\begin{array}{l}\text { Providing visible leadership supporting safety activities, such as } \\
\text { 1. Ensuring that polices for worker safety and health protection } \\
\text { are defined and communicated to all employees } \\
\text { 2. Helping to establish goals for the program and results- } \\
\text { oriented objectives for meeting the goal(s). } \\
\text { 3. Ensuring that goals and objectives are communicated to and } \\
\text { understood by all employees } \\
\text { 4. Establishing clear lines of communication with employees } \\
\text { 5. Setting an example of safe and healthy behavior } \\
\text { 6. Allowing reasonable access to management } \\
\text { 7. Ensuring all workers, including contractors, are provided } \\
\text { equally high quality safety and health protection } \\
\text { 8. Clearly defining employee responsibilities in writing } \\
\text { 9. Assigning commensurate authority to those who have } \\
\text { responsibility } \\
\text { 10. Providing adequate resources to support safety activities } \\
\text { 11. Holding managers, supervisors, and employees accountable } \\
\text { for their safety and health responsibilities } \\
\text { 12. Evaluating managers and supervisors annually } \\
\text { 13. Operating a documented system for correcting deficiencies } \\
\text { 14. Including safety and health in the overall management } \\
\text { planning process to include an annual evaluation to judge } \\
\text { success, and determine and implement improvements }\end{array}$ \\
\hline \multirow[t]{2}{*}{ Employee involvement } & $\begin{array}{l}\text { An individual's right to notify appropriate managers of hazardous } \\
\text { conditions and practices and to have issues addressed. }\end{array}$ \\
\hline & $\begin{array}{l}\text { Involvement in planning and implementing safety activities and in } \\
\text { decisions affecting employees' safety and health, such as } \\
\text { 1. Participating in safety and health problem-solving groups } \\
\text { 2. Participating in audits or worksite inspections } \\
\text { 3. Participating in accident and incident investigations } \\
\text { 4. Developing or participating in employee improvement } \\
\text { suggestion programs } \\
\text { 5. Training other employees in safety and health } \\
\text { 6. Analyzing job/process hazards } \\
\text { 7. Acting as safety observers } \\
\text { 8. Serving on safety and health committees constituted in } \\
\text { conformance to the National Labor Relations Act. }\end{array}$ \\
\hline $\begin{array}{l}\text { Contract worker } \\
\text { coverage }\end{array}$ & $\begin{array}{l}\text { 1. Requiring all contractors and subcontractors to follow } \\
\text { worksite safety and health rules and procedures } \\
\text { 2. Encouraging contractors to develop and operate effective } \\
\text { safety and health management systems } \\
\text { 3. Documenting the oversight and management system as it } \\
\text { applies to contractors }\end{array}$ \\
\hline
\end{tabular}

Source: [7] 


\section{Safety metrics and evaluation criteria ${ }^{5}$}

How do industry safety leaders measure and evaluate safety performance? Typically, they collect data supporting an array of measures that they then use to determine their performance relative to some benchmark, either internally or externally derived. Industry safety leaders do not look to a single measure as an indicator of success or failure in safety but rather to a combination of measures that reflect "upstream" activities (leading indicators) and "downstream" results (lagging indicators). They have found that relying only on downstream results may encourage people not to report mishaps. Consequently, they concentrate on measuring behavior and results because what gets measured is most likely to be what gets done. Using a combination of upstream and downstream measures also provides balance to the overall safety management system. Upstream indicators provide management and employees with a positive incentive to focus on risk control and prevention activities and underscore the idea that the best way to reduce injury and loss is to understand and take action to reduce risk. In this section, we

- Discuss common safety performance metrics and evaluation criteria used by industry leaders,

- Review safety performance metrics currently tracked by the Navy, and

- Make suggestions regarding performance measures the Navy should consider using as a means to encourage behavior that fosters a safety culture.

Downstream results typically capture the occurrence of mishaps, injuries, and illnesses. In occupational health and safety, downstream, rather than upstream, indicators are what are most commonly measured. OSHA recordkeeping requirements tend to influence the measures that organizations use. Examples of OSHA measures are the total case incident rate (TCIR), and the days away from work, restricted work activity, and job transfer (DART) rate. Others used by industry leaders include workers' compensation cost savings/increases and unit production increases/decreases. We list additional examples in table 4.

Industry leaders in safety tend to adopt an overall goal of zero: zero fatalities, zero lost workday injuries, and zero mishaps. For most organizations, an employee fatality due to occupational hazards is a rare event and many times when an organization experiences the accidental death of an employee it is due to a motor vehicle accident. Consequently, there is a growing trend among industry leaders in safety to incorporate driving and recreational off-duty safety training in their health, safety, and environment activities and initiatives.

\footnotetext{
${ }^{5}$ Unless otherwise noted in this section, we draw from information found in references [8] through [13].
} 
Table 4. Examples of downstream and upstream safety measures

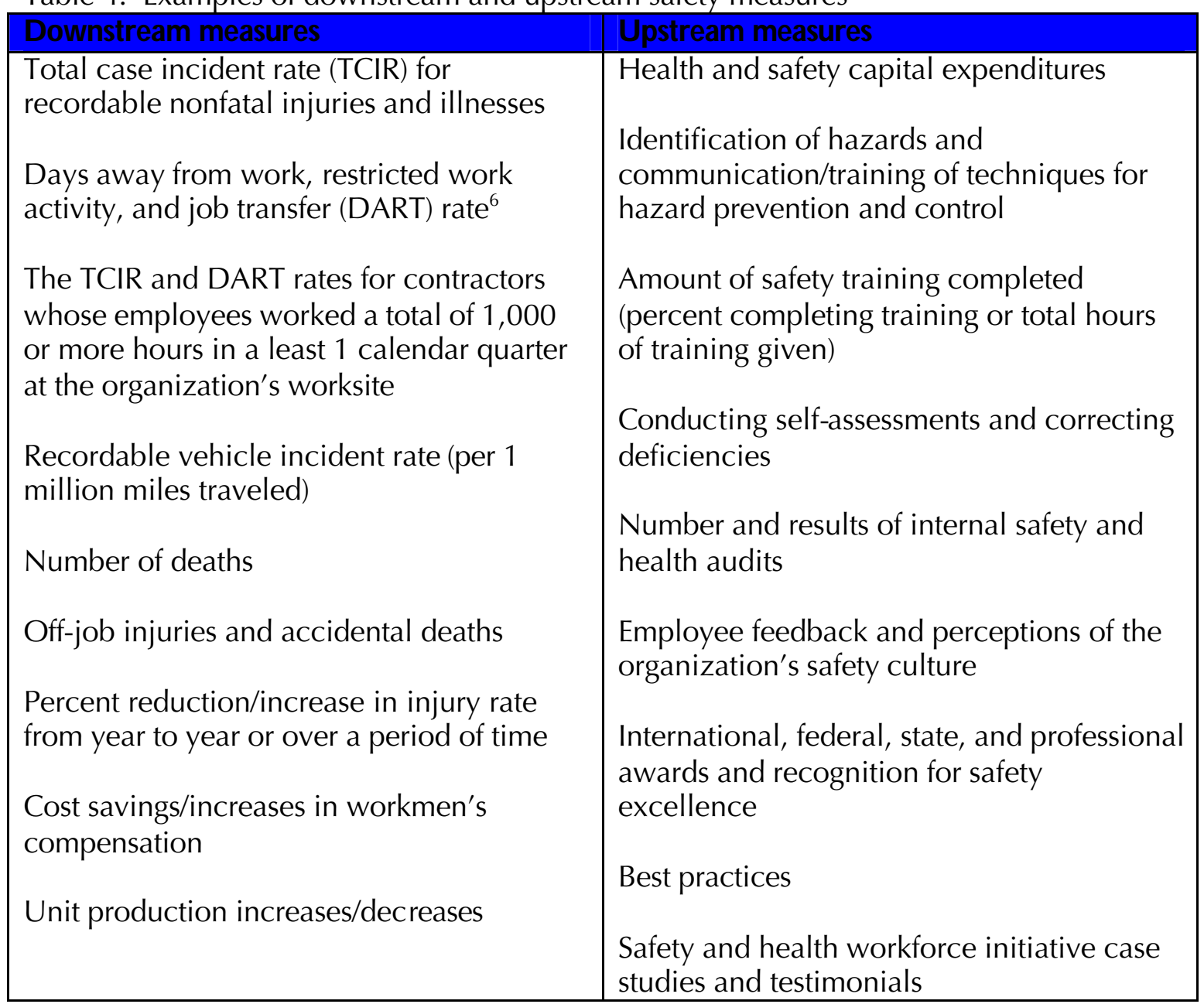

In table 4, we also list examples of upstream measures, which focus on risk control and prevention. These measures concentrate on maximizing safety performance by measuring, reporting, and managing safe behaviors - namely those actions taken to prevent accidents. They reflect how organizations go about achieving their safety goals. And tend to be directly related to more specific, relatively short-term, safety objectives. Dynamic in nature, these measures can be changed to reflect new risk control and prevention activities. For example, as part of its 2020 strategic plan for cleaner air, better use of land and water, and the protection of human health, Alcoa [14] set the following goals in 2004:

- Locations will control 50-percent or more of their significant ergonomic risks by year-end 2005.

\footnotetext{
${ }^{6}$ OSHA recently has adopted the DART rate as the successor term to Lost Workday Injury and Illness (LWDII) rate.
} 
- Locations will achieve a 25 -percent reduction in the incident rate of new work-related hearing shifts as compared to the hearing shift rate that exists for annualized year-end 2003 data $o r$ attainment of a $1 \%$ or lower incident rate of new work-related hearing shifts by year-end 2005 .

- 60-percent or more reduction in number or magnitude of unacceptable employee chemical agent exposures by year-end 2005.

- All locations will have in place a mechanism for collecting and storing personal health risk data by year-end 2004 .

- All locations will have in place an influenza vaccination program by year-end 2004.

- All locations will adopt no smoking strategies and offer a smoking cessation program by year-end 2004.

- All locations will achieve "Good" rating for asbestos from audit or self-assessment scores by year-end 2004.

Notably, six of Alcoa's seven "short-term" goals for 2004 focus on upstream activities that provide leading indicators of safety. Only one is a downstream result: the incidence of work-related hearing shifts. Alcoa's overall goal of zero remains constant and it tracks its performance in meeting this goal on a daily basis.

Overall, short-term and long-term safety goals and objectives provide the yardstick by which organizations evaluate their progress. General types of evaluation criteria include

- Comparison to historical corporate performance

- Quarterly/yearly progress in reaching short-term and long-term corporate safety and health goals

- Compliance with OSHA standards

- Comparison to the injury/illness and lost workday rates with the current industry average (as published by the Bureau of Labor Statistics or the National Safety Council)

- OSHA VPP requirements.

In similar fashion, the Navy also regularly defines short-term strategic goals for safety. For example, the Naval Safety Center outlined its five overall goals and objectives in its strategic plan for 2002-2005. Their goals include:

- Establishing the Naval Safety Council

- Aligning culture workshops

- Formalizing and institutionalizing Operational Risk Management (ORM) training throughout Navy and Marine Corps

- Increasing safety awareness throughout the Fleet 
- Serving as the Marketing Department and Public Affairs Office for both the Naval Safety Center and Marine Corps Safety Division $[15]{ }^{7}$

In 2003, Secretary of Defense Rumsfeld challenged the military services to reduce their mishap rates by 50-percent by the end of fiscal year 2005 . In 2004, the Department of the Navy's overall objectives include: reducing mishaps to be on target for a 50-percent reduction from fiscal years 2002 to 2005 [16]. The Secretary of the Navy outlined specific activities that all Navy Commanders should be taking to support the 50percent reduction goal including full funding of safety programs, involving leadership at all levels, ensuring senior supervision is present during high risk evolutions, integrating ORM into all endeavors, and ensuring that all safety officers have access to their Commanders on all safety issues [17].

The Navy and Marine Corps Safety Council and the USMC Safety Program also have each defined a plan of attack and milestones for meeting the 50-percent mishap reduction goal. Recently, COMSUBPAC Pearl Harbor conveyed their three-pronged approach to SUBPAC for achieving the 50-percent reduction safety goal including fielding the Afloat Safety Climate Assessment Survey during each ship's fleet readiness training program cycle, incorporating operational risk management (ORM) training into fleet indoctrination and continuing training programs, and accomplishing the required traffic safety training [18]. Notably, commands and communities throughout the Navy and Marine Corps are setting safety goals that they can use to identify upstream measures of safety that indicate the extent to which actual behavior and daily activities support safety. However, we were not able to find evidence that data are being collected and reported to Navy and Marine Corps leadership on such leading indicators.

An organization's safety culture also may be used as an upstream indicator related to the occurrence of mishaps. Some industry leaders use employee feedback and safety surveys to provide them with data reflecting the current safety climate, where the safety climate "can be regarded as the surface features of the safety culture discerned from the workforce's attitudes and perceptions at a given point in time" (See [19], p. 178.) Since 1996, the Navy and Marine Corps aviation communities have used a Maintenance Climate Assessment Survey (MCAS) and Command Assessment Survey (CAS) as a way to gauge the extent to which squadrons and maintenance crews are fostering a safety culture and integrating safety into their daily work activities. Based on the positive experience of the aviation community with their safety climate surveys,

\footnotetext{
${ }^{7}$ Note that the Safety Center defined these goals prior to Secretary's Rumsfeld's challenge in 2003 to reduce the mishap rate by 50 percent by the end of fiscal year 2005 .
} 
the afloat community, with the assistance of the Afloat Safety Division of the Naval Safety Center, decided to provide ships and submarines with a similar tool that became available for Fleet use in October 2003. Results of these climate assessment surveys are provided to the commander of the specific squadron, ship, or submarine taking the survey. Unfortunately, there are no efforts underway to analyze these survey data across platforms to determine what broader patterns may be occurring that might be related to trends in mishap rates or that might be addressed through more attention to the topic of safety in existing training programs.

The Navy does track a number of downstream results reflecting annual safety performance and monthly results for the current year. The Navy and Marine Corps define mishaps in terms of three criteria: the total cost of the property damage, the incidence of a fatality or disabling nature of injuries, and time loss from work. Specific definitions are in table 5.

Table 5. Mishap definitions by class

\begin{tabular}{|c|l|l|}
\hline $\begin{array}{c}\text { Mishap } \\
\text { class }\end{array}$ & \multicolumn{1}{|c|}{ Total Property Damage } & \multicolumn{1}{c|}{ Fatality/lnjury } \\
\hline A & $\begin{array}{l}\text { Total property damage of } \$ 1,000,000 \\
\text { or more and/or aircraft destroyed }\end{array}$ & Fatality or permanent total disability \\
\hline B & \begin{tabular}{|l|l|}
$\$ 200,000$ or more but less than \$1M \\
C
\end{tabular} & $\begin{array}{l}\text { Permanent partial disability or three } \\
\text { or more persons hospitalized as } \\
\text { inpatients }\end{array}$ \\
\hline 220,000 or more but less than \$200K & $\begin{array}{l}\text { Nonfatal injury resulting in loss of } \\
\text { time from work beyond day/shift } \\
\text { when injury occurred }\end{array}$ \\
\hline
\end{tabular}

Source: [20].

The Marine Corps requires that all Class A, B, and $\mathrm{C}$ ground mishaps be reported; however, they do not require all Class $\mathrm{C}$ aviation mishaps to be reported. The Navy requires that all Class A and B mishaps be reported; however, they do not require the reporting of all Class C Navy afloat, ashore, and aviation mishaps. For most afloat and ashore mishaps that are reportable due to injuries, the Navy requires that the active duty member or civilian employee experience a minimum of five lost workdays before the mishap must be reported. The Navy regularly tracks and publicly reports via the Naval Safety Center Internet website on Class A mishaps and fatalities in the Navy and Marine Corps. Measures include the current number of mishaps, and the current year rates with comparisons to previous years, current year goals, and the FY 2005 50-percent reduction goal for the following categories:

- Private motor vehicle (MV)

- Total Class A operational

- Aviation Class A flight

- Marine Corps Ground Class A 
- Ashore Class A operational excluding MV

- Operational MV Class A

- Afloat Class A operational

- Total Navy/Marine Corps operational

- Off-duty shore and recreational.

The Navy also tracks and reports the annual number of Class B and C injuries, illnesses, lost workdays, and associated costs for active duty members or civilian employees. The Navy's annual report on Occupational Safety and Health provides annual performance results including Office of Worker's Compensation Program injury and illness data, total case rates, compensation costs, and continuation of pay costs. The Naval Safety Center's Occupational Safety and Health division also keeps track of annual fatality and injury frequencies and rates for civilian employees and active duty members. However, we found overall that the Navy places much greater emphasis on closely tracking fatalities and Class A mishaps. It is concerning that less attention is placed on class B and $\mathrm{C}$ mishaps. Class $\mathrm{B}$ and $\mathrm{C}$ mishaps tend to occur with greater frequency and present the greater potential for risk prevention, control, and cost savings. Additionally, a growing pattern of a specific type of Class B or C mishap may be signaling a condition that could one day turn into a Class A mishap. The Navy needs to invest more attention to Class $\mathrm{B}$ and $\mathrm{C}$ mishaps by regularly tracking and reporting on the frequency for these mishaps, investigating and analyzing root causes, and developing and implementing risk controls and preventive measures.

\section{Safety compliance techniques}

How do industry leaders ensure that their managers and employees are complying with and meeting safety requirements? They hold top-level executives accountable for safety performance. They require regular selfassessments, internal audits, and evaluations; they receive external audits by organizations such as OSHA; and they require top-level executives to report regularly to the CEO and corporate board of directors on the status of occupational health and safety performance for their respective operating divisions. Industry leaders tend to tie some part of annual bonuses to safety performance. Consistent poor performance or clear cases of negligence can place jobs in jeopardy. In this section, we describe how the General Electric Company approaches safety compliance and compare its approach to that used by the Navy.

General Electric monitors safety performance and compliance with its environmental, health and safety (EHS) program and policies by requiring facility inspections and evaluations, providing auditing tools and employee training, requiring reporting and dissemination of best practices, 
and involving employees at all levels. Facility inspections and evaluations occur regularly throughout the year. Each week, ESH personnel and plant managers use checklists to assess performance and identify potential hazards. Each GE facility also conducts annual self-assessments. The Corporate Environmental Program team undertakes focused operating reviews and an independent, third party compliance audit occurs at each GE facility every 24 to 36 months.

GE makes sure that EHS personnel and GE managers have access to information on safety performance on a daily basis. All information collected during the self-assessments, operating reviews, and internal and external audits is entered into a Web-based tool. GE uses this Web-based tool to manage all EHS activities. Through the use of "digital cockpits," EHS personnel and GE managers can access facility safety performance data on a daily basis. Plant managers can determine current safety issues that staff needs to address; regional managers can monitor audit findings and injury and illness trends at a specific site; GE corporate leaders can access current performance indicators and trend information. Managers submit EHS performance and safety activity measures to EHS headquarters each month. Line managers report on their divisions' EHS performance to GE business leaders and the corporate EHS team during GE's annual corporate meetings. During these meetings, GE's leadership discusses the prior year's performance, current performance, upcoming commitments, and areas for improvement. Managers also share best practices that may be used by other GE operations.

GE requires all employees to complete a certain amount of environmental, health and safety training. All employees must be aware of current EHS policies and be able to identify potential hazards. Through its training programs, GE provides its employees with a common framework of environmental, health, and safety expectations. GE conducts more than 1.3 million units of EHS training each year and also provides Web- and CD-ROM-based training in 17 languages to ensure consistency throughout its global operations. Because GE has operating facilities in almost every country in the world, they require each plant to be fully cognizant of the regulatory requirements unique to its locale in addition to GE's corporate requirements. Plant managers participate in a 2-day interactive training course for operations leaders on their EHS responsibilities and accountability. GE gives this course worldwide 20 to 25 times a year to roughly 800 attendees. In addition, GE has created Web-based, multilanguage, country-specific, compliance checklists for 21 countries.

Finally, GE encourages employee involvement in EHS activities by pursuing VPP recognition from government programs in countries where GE has operating facilities. A common requirement for recognition and certification by these programs is active employee involvement. For those 
GE facilities located in countries that do not have government safety recognition programs, GE has created its own health and safety excellence program, Global Star, modeled on OSHA's VPP.

In comparison, the Navy does not have a compliance system in place that links performance with people in leadership positions at all levels of command, including the unit level. We found no evidence indicating whether or how the Secretary of the Navy holds his top-level civilian officials and flag officers accountable for safety performance. Does the Navy proactively assist commands that are struggling with poor safety performance? Are there eventually consequences for a consistent pattern of poor safety performance?

Inspections and Surveys conduct formal evaluations of individual commands every 2 to 3 years. Informal assessments by the Naval Safety Center also tend to occur every 2 to 3 years. There is no formal requirement that commands conduct self-assessments and provide reports up through the chain of command on their annual safety performance. However, the newly chartered Navy and Marine Corps Safety Council could provide a forum for ensuring safety compliance by requiring each member to report at meetings on leading and lagging indicators of safety performance for his communities. Such a requirement would provide a strong top-down incentive for the Navy and Marine Corps to require selfassessments, safety audits, and regular reports on safety through their respective chains-of-command. 


\section{Making a business case for safety}

Industry safety leaders often highlight the cost savings that come with outstanding safety performance in terms of such factors as lower workers' compensation costs, the absence of OSHA fines, higher worker productivity, and higher employee satisfaction levels. Making a business case for safety requires having a complete picture of all safety and occupational health costs and being able to show the impact of safety performance on the corporate bottom line. This includes knowing how much an organization spends and saves due to prevention and detection activities versus how much it spends and loses due to safety failures.

The DASN (Safety) wants to bring visibility to the total costs of Navy Safety. In this section, we describe a basic framework that the Navy can use to analyze the business impact of safety. Next, we identify current visible funding of Navy Safety activities in this section. Finally, we recommend an approach for determining operational forces' and field commands' safety costs.

\section{A framework for building a business case for safety}

Building upon the quality management literature, Behm and his colleagues [21] provide a framework for using the cost of quality model introduced by Coble et al. [22] for building a business case for safety. Behm [20] notes that the cost of quality framework has four main activity groups that are easily applicable to safety: prevention, detection, internal failure, and external failure. When thinking about the costs associated with safety activities, these groups succinctly capture the two continuums of safety: upstream (proactive) activities, and downstream (reactive) activities and results.

As noted earlier in our section on performance metrics, prevention and detection activities occur upstream in the work process; they are proactive measures taken by an organization to invest in the safety of an organization. Prevention and detection activities are how organizations translate talking about safety into the reality of fostering a safety culture. In analyzing overall effectiveness of safety activities, prevention and detection costs are combined because they reflect an organization's investment in proactive measures to minimize failures. Prevention activities focus on keeping mishaps and failures from ever occurring. They may be funded on a discretionary basis and include such activities as employee training, the purchase and provision of personal protective equipment, and the involvement of safety and occupational health professionals in the design of new products and processes. Detection 
focuses on identifying and correcting defects that have already occurred but have not resulted in a mishap. They include inspections, safety audits, correction of deficiencies before a mishap occurs, and other quality control measures.

Internal and external failures represent the costs that come with the consequences of and reactions to safety failures. Internal failures occur inside an organization and reflect incidents and mishaps that organizations try to avoid through prevention and detection activities. Examples of internal failure costs include healthcare costs, workers' compensation, incident investigations, employee replacement and training, property damage, lost production, and correction of deficiencies after an injury occurs. External failures are the costs for products or services that are passed on to the customer or distributor. They include product recalls, warranty costs, consumer boycotts, regulatory fines, administrative costs of dealing with external agencies, and public-image issues.

The cost of safety model (see figure 2) evaluates trends in both continuums of safety costs over time. With the required cost data in hand and using linear regression techniques, it is possible to determine the relationship between each cost continuum and an organization's safety levels over time. A lower investment in prevention and detection activities is expected to yield poorer safety performance, which will also be associated with higher internal and external failure costs. As an organization invests more in prevention and detection activities, safety levels should improve and internal and external failure costs should decrease.

Figure 2. Cost of quality (safety) model

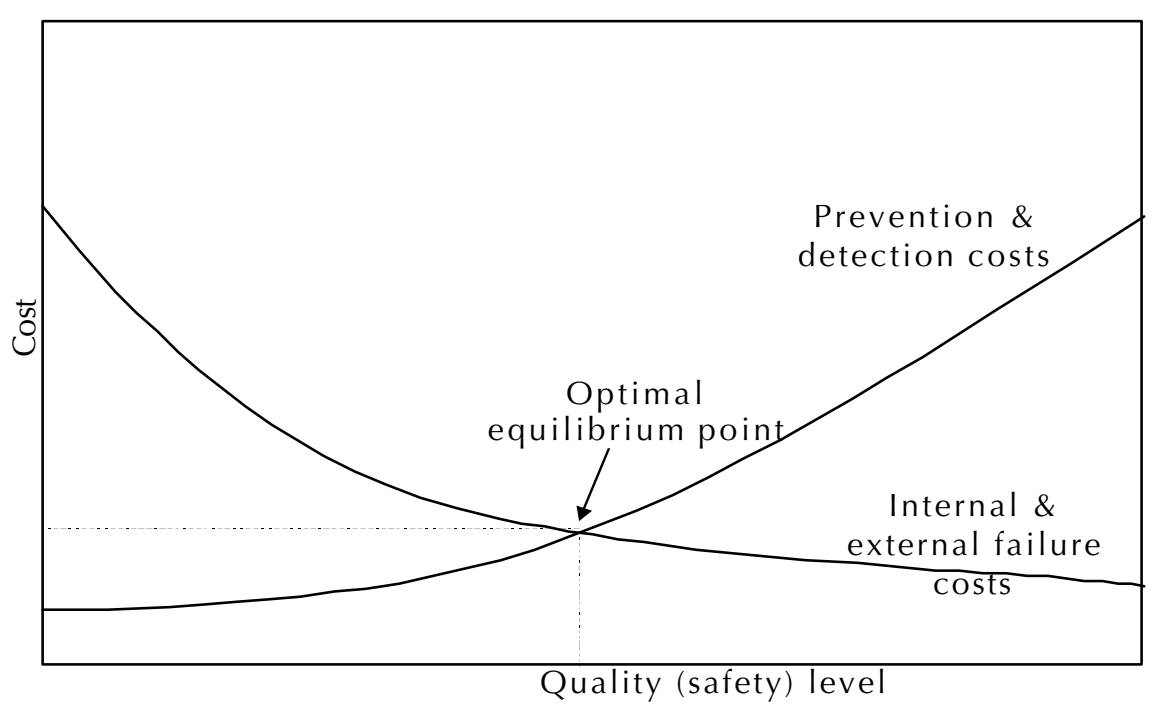


The underlying theory of the model is based upon an optimal-cost approach. Theoretically, the model posits that an optimal equilibrium point exists where total prevention and detection costs equal total internal and external failure costs. Using linear regression techniques, it is possible to determine budget amounts for prevention and detection activities that will yield failures, but at a level where total safety costs are minimized or optimal. The cost of safety model assumes that the goal of zero, while appealing, is not possible without a significant monetary investment in prevention and detection activities. The optimal-cost approach minimizes failures to the point that an organization invests only what is necessary to minimize the overall safety costs.

\section{Current Navy safety resources}

The cost of quality framework provides a potential approach that the Navy can use to help make a business case for safety. However, in order to apply its experience to this model, the Navy must be able to identify and separate the costs associated with its proactive investments in safety (prevention and detection activities) and with its reactive costs associated with safety failures. It also needs to track these costs over time in order to support the longitudinal requirements of the cost of safety model.

Unfortunately, as noted above, the Navy currently does not know how much it spends on the four main cost activity group s-prevention, detection, internal failure, and external failure-nor does it know the extent to which safety performance affects its bottom-line, which is readiness. Those safety costs that are known tend to be reactive costs. Proactive costs are more challenging to identify. The Navy, like many organizations, experiences difficulties in tracking costs supporting safety because safety activities are not uniformly funded as a separate line item, nor do they always occur as a separate function. For most Navy commands and Marine Corps units, attention to safety is a collateral activity and there is no separate cost element in the budget process that identifies the funding for afloat, aviation, or ground safety activities. Aside from the budgets for the Naval Safety Center and the Headquarters (HQ) Marine Corps Safety Division, ${ }^{8}$ only the ashore community has a separate cost element for safety.

From the ashore budget, it is possible to identify funds for Explosive Safety, Navy Occupational Safety and Health (NAVOSH), Recreational/Off Duty Safety, and Traffic Safety. In table 6, we provide total identifiable Navy Safety funding allocations for FY 2004 and those projected for FY 2005. Combined, these support programs initially were

\footnotetext{
${ }^{8}$ We are awaiting final data inputs from the HQ USMC Safety Division regarding their current funding for FY 2004 and projected funding for FY 2005.
} 
scheduled to receive nearly $\$ 53$ million in FY 2004 and a projected increase of 12-percent in funding levels for FY 2005. Next, we will examine aspects of the funding for the Naval Safety Center and Navy ashore safety and highlight what the Navy can and cannot glean from this data with respect to using these data to make a business case for safety.

Table 6. Identified Navy Safety Funding, budgeted for FY 2004(a), projected for FY 2005

\begin{tabular}{|l|l|r|l|r|}
\hline Navy safety program & \multicolumn{1}{|c|}{$\begin{array}{c}\mathrm{FY}^{\prime} 04 \\
\text { Funding }(\$ K)\end{array}$} & $\begin{array}{c}\text { \% of } \\
\text { Total }\end{array}$ & $\begin{array}{c}\text { FY } 05 \\
\text { Funding } \\
\text { Estimate }(\$ K)\end{array}$ & $\begin{array}{c}\text { \% of } \\
\text { Total }\end{array}$ \\
\hline Naval Safety Center & $9,973(\mathrm{~b})$ & 20 & $9,574(\mathrm{~b})$ & 17 \\
\hline HQMC Safety Division & $1,200(\mathrm{c})$ & 2 & $1,200(\mathrm{c})$ & 2 \\
\hline Ashore & 40,351 & 78 & 46,981 & 81 \\
\hline Aviation & unknown & -- & unknown & -- \\
\hline Afloat & unknown & -- & unknown & -- \\
\hline Total & $\mathbf{5 1 , 5 2 4 ( a )}$ & 100 & $\mathbf{5 7 , 7 5 5}$ & 100 \\
\hline
\end{tabular}

a.) Reported figures represented initially scheduled distribution of funds for FY 2004; they do not reflect final funding numbers which may be lower due to DoD funding cuts to offset costs of U.S. military operations in Iraq.

b.) Does not include compensation for military personnel.

c.) Represents budget for office operations only; does not include civilian or military personnel compensation.

\section{Naval Safety Center}

The Naval Safety Center oversees a network of safety, training, education, and mishap-prevention programs for the Navy and Marine Corps. It serves as the Navy and Marine Corps "one-stop safety shop" and operates programs for the afloat, ashore, and aviation communities and also supports and integrates its services with the Marine Corps Safety Division. It is responsible for reviewing Navy and Marine Corps safety in the areas of aviation, submarine, surface ship, occupational safety and health, and recreational/off-duty safety. Safety Center activities include participating in mishap investigations; conducting safety surveys and seminars, oversight reviews, assist visits, culture workshops, and safety officer workshops; ensuring that every Sailor and Marine receives operational risk management training; and gathering near-miss and safety failure data through a computerized repository for reports on injuries, occupational illnesses, and property damage.

The Naval Safety Center is an echelon-two command, and the Commander, Naval Safety Center, directly answers to the Chief of Naval Operations and the Secretary of the Navy as a special advisor for managing aviation, afloat, and ashore safety activities for the Navy and Marine Corps. The Naval Safety Center is located at Naval Station 
Norfolk and has roughly 200 civilian and military staff members who provide support to more than 4,200 commands and detachments worldwide.

The Naval Safety Center has maintained historical records on its budget and provided us with budget data from 1981 through the current fiscal year, as well as estimated funding levels for fiscal years 2005 through 2007. We show the Safety Center's current and estimated funding for fiscal years 2004 through 2006 in table 7. The Safety Center budget data did not include compensation expenses for active duty personnel. ${ }^{9}$ Currently, its budget for FY 2004 is \$9.9 million, nearly three-quarters of which provides compensation to the Safety Center's 98 civilian personnel members (see table 8 for a breakdown of the Safety Center's staffing). Roughly 10 percent of the Naval Safety Center's FY 2004 budget supports travel expenses primarily for conducting safety surveys and mishap investigations. Nearly 12 percent of its budget goes toward other miscellaneous purchases for subcontracts, new equipment, and maintenance.

Table 7: Naval Safety Center current and estimated future funding, FY 2004 to 2006

\begin{tabular}{|c|c|c|c|c|c|c|}
\hline Investment cost code & $\begin{array}{l}\mathrm{FY}^{\prime} 04 \\
\text { funding } \\
\text { received } \\
(\$ K)\end{array}$ & $\begin{array}{l}\% \text { of } \\
\text { total }\end{array}$ & $\begin{array}{c}\text { FY'05 } \\
\text { funding } \\
\text { estimate } \\
(\$ K)\end{array}$ & $\begin{array}{l}\% \text { of } \\
\text { total }\end{array}$ & $\begin{array}{c}\text { FY'06 } \\
\text { funding } \\
\text { estimate } \\
(\$ K)\end{array}$ & $\begin{array}{l}\% \text { of } \\
\text { total }\end{array}$ \\
\hline $\begin{array}{l}\text { Civilian personnel } \\
\text { compensation }\end{array}$ & 7,368 & $73.9 \%$ & 7,768 & $81.1 \%$ & 7,800 & $77.1 \%$ \\
\hline FECA & 0 & $0.0 \%$ & 0 & $0.0 \%$ & 0 & $0.0 \%$ \\
\hline Travel & 1008 & $10.1 \%$ & 165 & $1.7 \%$ & 475 & $4.7 \%$ \\
\hline $\begin{array}{l}\text { Stock fund supplies } \\
\text { and materials } \\
\text { purchases }\end{array}$ & 50 & $0.5 \%$ & 51 & $0.5 \%$ & 52 & $0.5 \%$ \\
\hline $\begin{array}{l}\text { Stock fund equipment } \\
\text { purchases }\end{array}$ & 170 & $1.7 \%$ & 20 & $0.2 \%$ & 102 & $1.0 \%$ \\
\hline $\begin{array}{l}\text { Industrial fund } \\
\text { purchases }\end{array}$ & 217 & $2.2 \%$ & 0 & $0.0 \%$ & 224 & $2.2 \%$ \\
\hline Other purchases & 1,160 & $11.6 \%$ & 1,570 & $16.4 \%$ & 1,469 & $14.5 \%$ \\
\hline Total & 9,973 & & 9,574 & & 10,122 & \\
\hline
\end{tabular}

\footnotetext{
${ }^{9}$ We are able to estimate compensation costs for active duty Navy personnel assigned to the Safety Center in FY 2004 by using the standard composite rates published by the DoD Office of the Comptroller. The Office of the Comptroller computes the standard composite rates each fiscal year following the submission of the President's Budget to Congress. Consequently, the rates for fiscal years 2005 and 2006 are not available and we are not able to provide active duty compensation estimates for these years. Using the standard composite rates for FY 2004, we estimate that Navy compensation of active duty Navy personnel assigned to the Safety Center was approximately $\$ 10.8$ million.
} 
In FY 2005, the Naval Safety Center is scheduled to receive an overall decrease of 4 percent in its budget as compared to its FY 2004 funding level. Currently, the Safety Center anticipates that this funding decrease will reduce its travel budget by 84 percent and its safety publications budget, which falls under "other purchase," by 70 percent. Over half of the estimated funding for "other purchases" is scheduled to support Navy Marine Corps Intranet (NMCI) Infrastructure expenses. Funding support of NMCI Infrastructure becomes a major cost component under the "other purchases" category, while other components will decrease to offset NMCI Infrastructure costs. Essentially, the Safety Center will not be able to fully participate in mishap investigations or to conduct safety surveys, and the current plan is to curtail publication of its safety magazines for the ashore, afloat, and aviation communities. Additionally, as shown in table 8 , it is scheduled to cut 14 reserve officers from its FTE authorization. In FY 2006, current funding estimates for the Naval Safety Center indicate that it will receive an overall increase in funding of 5.7 percent compared to the estimated FY 2005 funding level. This will allow travel funding levels to be somewhat restored to support mishap investigation activities and safety surveys.

Table 8: Naval Safety Center personnel authorizations, FY 2004 to 2006

\begin{tabular}{|c|c|c|c|}
\hline Investment cost code & $\begin{array}{l}\text { FY'04 } \\
\text { actual }\end{array}$ & $\begin{array}{l}\text { FY'05 } \\
\text { estimate }\end{array}$ & $\begin{array}{l}\text { FY'06 } \\
\text { estimate }\end{array}$ \\
\hline Military officer & 54 & 53 & 52 \\
\hline Military enlisted & 45 & 45 & 45 \\
\hline $\begin{array}{l}\text { Reserve military } \\
\text { officers }\end{array}$ & 15 & 1 & 1 \\
\hline $\begin{array}{l}\text { Reserve military } \\
\text { enlisted }\end{array}$ & 26 & 26 & 26 \\
\hline Civilian FTEs (Navy) & 98 & 97 & 94 \\
\hline Total & 238 & 222 & 218 \\
\hline
\end{tabular}

\section{Ashore safety}

The Navy currently supports its ashore safety activities through the Commander, Navy Installations (CNI) located in Washington, DC. The CNI provides guidance, funding, and other administrative support to 18 regional commanders located worldwide. The CNI ashore budget is broken down into the four appropriation categories of Operation and Maintenance, Navy (OMN); Other Procurement, Navy (OPN); Operation and Maintenance, Navy Reserve (OMNR); and Family Housing, Operation and Construction Navy (FHOCN). Support for safety activities and personnel are funded under the OMN appropriation. CNI has identified and developed core business areas to manage each of the 
different ashore base business areas. Safety falls under Public Safety in the Base Support area. It is broken down into four primary focus areas: explosive safety, Navy occup ational safety and health (NAVOSH), recreational/off duty safety (RODS), and traffic safety.

Through use of the newly developed capabilities-based budgeting model, we identified budget allocations for each of the four ashore focus areas. In table 9, we provide the ashore safety allocations for FY 2004. Ashore safety was budgeted to receive roughly $\$ 40$ million. Slightly over threequarters of total budgeted ashore safety funds were allocated to NAVOSH. The initial funding levels have been set for the upcoming fiscal year as part of the FY 2005 Department of Navy Budget Submission; we show the ashore safety portion in table 10 .

Comparing this year's allocations with the proposed FY 2005 budget, we find that the relative distribution of funding across areas remains about the same. All functional areas show growth with the exception of Traffic Safety. Explosive safety and recreational/off-duty safety are scheduled to receive allocations representing nearly twice their FY 2004 budget levels (however, keep in mind that these programs are still relatively small in

Table 9. FY 2004 Navy capability-based budget allocation for ashore safety

\begin{tabular}{|c|c|c|c|c|c|c|}
\hline & \multirow{2}{*}{$\begin{array}{l}\text { Total funding } \\
(\$ \mathrm{~K})\end{array}$} & \multirow[b]{2}{*}{$\%$ of total } & \multirow{2}{*}{$\begin{array}{l}\text { Military } \\
\text { (FTE) }\end{array}$} & \multicolumn{2}{|l|}{ Civilian } & \multirow{2}{*}{$\begin{array}{l}\text { Contractor } \\
\text { (FTE) }\end{array}$} \\
\hline & & & & \begin{tabular}{|l} 
Direct \\
(FTE)
\end{tabular} & $\begin{array}{l}\text { Reimb } \\
\text { (FTE) }\end{array}$ & \\
\hline Explosive safety & 2,352 & $5.8 \%$ & 4.00 & 31.65 & & \\
\hline NAVOSH & 31,599 & $78.3 \%$ & 29.25 & 374.20 & 28.15 & 16.00 \\
\hline Recreational/off-duty safety & 1,278 & $3.2 \%$ & 2.00 & 21.50 & 0.10 & \\
\hline Traffic safety & 5,122 & $12.7 \%$ & 2.00 & 31.55 & 1.00 & \\
\hline Safety total & 40,351 & & 37.25 & 45990 & 29.25 & 16.00 \\
\hline
\end{tabular}

Source: [23].

Table 10: FY 2005 Navy capability-based budget allocation for ashore safety FY05 Navy Capabilities Based Budget Allocation

\begin{tabular}{|c|c|c|c|c|c|c|}
\hline & \multirow[b]{2}{*}{$\begin{array}{l}\text { Total funding } \\
\qquad(\$ K)\end{array}$} & \multirow[b]{2}{*}{$\%$ of total } & \multirow[b]{2}{*}{$\begin{array}{c}\text { Military } \\
\text { (FTE) }\end{array}$} & \multicolumn{2}{|c|}{ Civilian } & \multirow[b]{2}{*}{$\begin{array}{l}\text { Contracto } \\
\text { (FTE) }\end{array}$} \\
\hline & & & & $\begin{array}{c}\text { Direct } \\
\text { (FTE) }\end{array}$ & $\begin{array}{c}\text { Reimb } \\
\text { (FTE) }\end{array}$ & \\
\hline Explosive safety & 4,473 & $9.5 \%$ & 3.70 & 48.88 & 2.81 & \\
\hline $\mathrm{NAVOSH}$ & 35,275 & $75.1 \%$ & 14.84 & 366.61 & 33.65 & 16.36 \\
\hline Recreational/off-duty safety & 2,581 & $5.5 \%$ & 0.13 & 27.37 & 0.62 & 0.36 \\
\hline Traffic safety & 4,651 & $9.9 \%$ & 0.85 & 48.36 & 6.40 & 0.39 \\
\hline Safety total & 46,980 & & 19.52 & 491.22 & 43.48 & 17.11 \\
\hline
\end{tabular}

Source: [24]. 
absolute terms). NAVOSH is scheduled for a more modest increase of 11percent and traffic safety's allocation decreases by 9 percent. Overall, an increase of $16.4 \%$ in total funding is proposed for FY 2005. Also, the Navy is migrating military safety billets into civilian and contractor positions. In terms of the total share of their available funding, both Traffic Safety and NAVOSH will decrease in terms of their respective shares; however, the ashore NAVOSH program funds are to increase.

In addition, as part of the overall Navy readiness reporting system, the Navy has established readiness measures for ashore safety to report installation safety program readiness condition in terms of capability levels. There are four levels ranging from fully capable (capability level 1 (CL-1)) to less than minimum capability (capability level 4 (CL-4)). ${ }^{10} \mathrm{We}$ provide the current definitions in table 11.

Table 11: Summary of ashore safety readiness condition classifications

\begin{tabular}{|c|l|}
\hline Readiness Condition & \multicolumn{1}{|c|}{ Safety Readiness } \\
\hline C1 & $\begin{array}{l}\text { Safety Office is fully staffed, educated, funded, and the Safety } \\
\text { and Occupational Health (SOH) program is in full } \\
\text { compliance with Navy, DoD, and Federal regulations and } \\
\text { standards. }\end{array}$ \\
\hline C2 & $\begin{array}{l}\text { Safety Office is not fully staffed, and is partially funded. } \\
\text { Education is ongoing. The SOH program is in partial } \\
\text { compliance with Navy, DoD and Federal regulations and } \\
\text { standards. Areas of non-compliance may affect the mission, } \\
\text { and may significantly increase the severity and frequency of } \\
\text { accidents. }\end{array}$ \\
\hline C3 & $\begin{array}{l}\text { Safety Office is minimally staffed and partially funded. } \\
\text { Education is inadequate, and the SOH program is not in } \\
\text { compliance with Navy, DoD and Federal regulations and } \\
\text { standards. Areas of non-compliance severely affect the } \\
\text { mission, and significantly increase the severity and frequency } \\
\text { of accidents. }\end{array}$ \\
\hline C4 & $\begin{array}{l}\text { Safety Office is inadequately staffed, educated, and funded. } \\
\text { The SOH program does not meet statutory Federal } \\
\text { requirements. Mishap rates are out of control. }\end{array}$ \\
\hline
\end{tabular}

Source: [25].

CNI directs resources to installations based on operational requirements and defined capability levels. CNI does not provide CL-1 funding for safety. Rather, it dedicates resources for safety at CL-3, which allows the Navy to meet some of its requirements. Given current funding constraints, it appears that shore safety readiness conditions will continue to be funded at less than $\mathrm{C} 1$. The Navy also has set readiness measures that indicate safety program readiness conditions by capability level. We provide the

\footnotetext{
${ }^{10} \mathrm{We}$ provide the current definitions of capability levels by each functional area for shore safety in the appendix.
} 
current C-3 safety definitions for ashore safety readiness classifications in table 12. During this project, we did not investigate whether actual safety performance is at the capability level 3 measurement thresholds or not and what impact safety performance really has on readiness. Developing an understanding of the connection between safety and readiness is an important aspect of making the business case for safety in the Navy.

Table 12. Summary of Navy ashore safety capability level 3 descriptions

\begin{tabular}{|c|c|}
\hline Sub-function & Description for capability level 3 \\
\hline Explosive safety & $\begin{array}{l}\text { Meets some of the Navy's explosives safety requirements per OP-5. } \\
\text { Support for management, coordination of programs, including but not } \\
\text { limited to management, inspections, evaluations, surveys, education, } \\
\text { training, instructions, and explosive mishap prevention. Performance } \\
\text { indicators: } \\
\text { - } 69-79 \% \text { of customers are identified and/or have ISSAMOAs } \\
\text { - } \quad 69-70 \% \text { of all training is performed } \\
\text { - } \quad 79-89 \% \text { of all required compliance evaluations are conducted } \\
\text { - } 69-79 \% \text { of all corrective actions are implemented } \\
\quad 69-79 \% \text { staffing per validated work plan }\end{array}$ \\
\hline NAVOSH & $\begin{array}{l}\text { Meets some of the Navy's OCCupational safety and health (NAVOSH) } \\
\text { requirements per OPNAVINST } 5100.23 \text { series. Support for } \\
\text { management, coordination of region-wide program, including but not } \\
\text { limited to management, inspections, evaluations, surveys, education, } \\
\text { training, instructions, mishap prevention, accident investigation and } \\
\text { reporting, and other activities involved with the operation of the } \\
\text { NAVOSH program. Performance indicators: } \\
\text { - } \quad 7-26 \% \text { injuries/illnesses are directly related to work process } \\
\text { - } \quad 26-74 \% \text { of customers are identified and/or have ISSAMOAs } \\
\text { - } 51-74 \% \text { of all training is performed } \\
\text { - } \quad 75-74 \% \text { of all workplace inspections are conducted } \\
\text { - } \quad 61-74 \% \text { of all corrective actions are implemented }\end{array}$ \\
\hline $\begin{array}{l}\text { Recreational/off-duty } \\
\text { safety }\end{array}$ & $\begin{array}{l}\text { Meets some of the Navy's RODS program requirements per } \\
\text { OPNAVINST } 5100.25 \text { series. Support for management, coordination } \\
\text { of region-wide program, including but not limited to management, } \\
\text { inspections, evaluations, surveys, education, training, instructions, and } \\
\text { mishap prevention. Performance indicators: } \\
\text { - } 51-75 \% \text { ROD's training (military personnel) is conducted } \\
\text { - } \quad 75-79 \% \text { mishap investigations are performed } \\
\text { - } 61-74 \% \text { ROD's inspections are conducted }\end{array}$ \\
\hline Traffic safety & $\begin{array}{l}\text { Meets some of the Navy's traffic safety program requirements per } \\
\text { OPNAVINST } 5100.12 \text { series. Support for management, coordination } \\
\text { of region-wide program, including but not limited to management, } \\
\text { inspections, evaluations, surveys, education, training, instructions, and } \\
\text { mishap prevention. Performance indicators: } \\
\text { - } 51-74 \% \text { motorcycle, EVOC, and AAA training is conducted } \\
\text { - } \quad 61-74 \% \text { mishap investigations are performed } \\
\text { - } 61-74 \% \text { GMV (auto/equipment) inspections are conducted } \\
\text { - } 61-74 \% \text { roadway inspections are conducted }\end{array}$ \\
\hline
\end{tabular}

Source: [26]. 


\section{Conclusion}

Although the Navy does not have a history of fostering a safety culture as a core value throughout the organization, it has taken an important first step toward achieving change by creating the Navy-Marine Corps Safety Council. Private industry provides numerous examples of companies, both large and small that have grappled with poor safety performance, achieved change, and emerged as industry safety leaders. In sharing their experiences and approaches to fostering cultures of safety, industry safety leaders tend to emphasize the importance of leadership, commitment, accountability, employee involvement, and what they do to achieve excellence in safety performance. The challenge before the Navy and Marine Corps is to move beyond the first step of creating the Safety Council and channeling the leadership skills of the organization into activities that foster a safety culture. We have provided examples from industry leaders regarding ways to do this.

Industry safety leaders view safety as a core corporate value that directly affects their bottom line and gives them a competitive advantage. They emphasize (and report yearly in dollars) how much they save in terms of workers compensation and the impact of lower lost workdays on production and unit costs. The Navy and Marine Corps do not produce widgets and gadgets; they produce military forces that are ready to fight. The Navy can make a business case for safety by connecting safety to readiness, and there are frameworks that could serve as ready tools for undertaking this task. We have recommended one approach in this paper built from the quality management literature that the Navy can use to make a business case for safety. Additionally, the Navy needs to track lost work time and associated costs due to injury and illness rates on a regular basis. These rates should reflect lost work time for active duty members, federal civilian employees and contractors. Tracking lost work time for all components of its workforce will allow the Navy to better understand the impact (both real and potential) between safety and readiness. We recommend specifically that the Navy undertake further work that evaluates the impact of safety on readiness. 


\section{Appendix: Navy ashore capability level descriptions}

Table 13: Summary of Navy Shore Safety Capability Level Descriptions

\begin{tabular}{|c|c|c|}
\hline Sub-function & $\begin{array}{c}\text { Capability } \\
\text { level }\end{array}$ & Description \\
\hline \multirow[t]{4}{*}{ Explosive safety } & $C L-1$ & $\begin{array}{l}\text { Meet the Navy's Explosives Safety Requirements per } \\
\text { OP-5. Support for management, coordination of } \\
\text { Programs, including but not limited to management, } \\
\text { inspections, evaluations, surveys, education, training, } \\
\text { instructions, and Explosive Mishap prevention. } \\
\text { Performance indicators: } \\
\begin{array}{l}\text { - } \quad 90-100 \% \text { of customers are identified and/or have } \\
\text { ISSAMOA's } \\
\text { - } \quad 90-100 \% \text { of all training is performed } \\
\text { - } \quad 90 \% \text { of all compliance evaluations are conducted } \\
\text { - } 90-100 \% \text { of all corrective actions are implemented }\end{array}\end{array}$ \\
\hline & CL-2 & $\begin{array}{l}\text { Meet most of the Navy's Explosives Safety } \\
\text { Requirements per OP-5. Support for management, } \\
\text { coordination of Programs, including but not limited to } \\
\text { management, inspections, evaluations, surveys, } \\
\text { education, training, instructions, and Explosive Mishap } \\
\text { prevention. Performance indicators: } \\
\text { - } \quad 80-89 \% \text { of customers are identified and/or have } \\
\text { ISSA/MOA's } \\
\text { - } 80-89 \% \text { of all training is performed } \\
\text { - } \quad \text { conducted all required compliance evaluations are } \\
\text { - } 80-89 \% \text { of all corrective actions are implemented } \\
80-89 \% \text { staffing per validated work plan }\end{array}$ \\
\hline & CL-3 & $\begin{array}{l}\text { Meet some of the Navy's Explosives Safety } \\
\text { Requirements per OP-5. Support for management, } \\
\text { coordination of programs, including but not limited to } \\
\text { management, inspections, evaluations, surveys, } \\
\text { education, training, instructions, and Explosive Mishap } \\
\text { prevention. Performance indicators: } \\
\text { - } \quad 69-79 \% \text { of customers are identified and/or have } \\
\text { ISSAMOA's } \\
\text { - } 69-70 \% \text { of all training is performed } \\
\text { - } \quad 79-89 \% \text { of all required compliance evaluations are } \\
\text { - } 69-79 \% \text { of all corrective actions are implemented } \\
69-79 \% \text { staffing per validated work plan }\end{array}$ \\
\hline & CL-4 & $\begin{array}{l}\text { Does not meet the Navy's Explosives Safety } \\
\text { Requirements per OP-5. Support for management, } \\
\text { coordination of Programs, including but not limited to } \\
\text { management, inspections, evaluations, surveys, }\end{array}$ \\
\hline
\end{tabular}




\begin{tabular}{|c|c|c|}
\hline Sub-function & $\begin{array}{c}\text { Capability } \\
\text { level }\end{array}$ & Description \\
\hline & & $\begin{array}{l}\text { education, training, instructions, and Explosive Mishap } \\
\text { prevention. Performance indicators: } \\
\text { - Less than } 69 \% \text { of customers are identified and/or have } \\
\text { - ISSAMOAOA's } \\
\text { - Less than } 69 \% \text { of all training is performed } \\
\text { - Less than } 79 \% \text { of all required compliance evaluations are } \\
\text { - Less than } 69 \% \text { of all corrective actions are implemented } \\
\text { - Less than } 69 \% \text { staffing per validated work plan }\end{array}$ \\
\hline \multirow[t]{3}{*}{ NAVOSH } & CL-1 & $\begin{array}{l}\text { Meets all of Navy's Occupational Safety and Health } \\
\text { (NAVOSH) Requirements per OPNAVINST } 5100.23 \\
\text { series. Support for management, coordination of } \\
\text { region-wide program, including but not limited to } \\
\text { management, inspections, evaluations, surveys, } \\
\text { education, training, instructions, mishap prevention, } \\
\text { accident investigation and reporting, and other } \\
\text { activities involved with the operation of the NAVOSH } \\
\text { program. Performance indicators: } \\
\text { - } 0-5 \% \text { injuries/illnesses directly related to work process } \\
\text { - } 95-100 \% \text { of customers are identified and/or have } \\
\text { ISSA/MOA's } 90-100 \% \text { of all training is performed } \\
\text { - } 98-100 \% \text { of all workplace inspections are conducted } \\
\text { - } 95-100 \% \text { of all corrective actions are implemented } \\
\text { - } 90-100 \% \text { staffing (per OPNAVINST 5100.23) is } \\
\text { maintained }\end{array}$ \\
\hline & CL-2 & $\begin{array}{l}\text { Meets most of Navy's Occupational Safety and Health } \\
\text { (NAVOSH) Requirements per OPNAVINST } 5100.23 \\
\text { series. Support for management, coordination of } \\
\text { region-wide program, including but not limited to } \\
\text { management, inspections, evaluations, surveys, } \\
\text { education, training, instructions, mishap prevention, } \\
\text { accident investigation and reporting, and other } \\
\text { activities involved with the operation of the NAVOSH } \\
\text { program. Performance indicators: } \\
\text { - } 1-6 \% \text { injuries/illnesses directly related to work process } \\
\text { - } 75-90 \% \text { of customers are ide ntified and/or have } \\
\text { - } 15 S A \text { MOA's } \\
\text { - } 75-89 \% \text { of all training is performed } \\
\text { - } 75-97 \% \text { of all workplace inspections are conducted } \\
\text { - } 75-89 \% \text { of all corrective actions are implemented } \\
\text { taffing (per OPNAVINST 5100.23) is maintained }\end{array}$ \\
\hline & $\mathrm{CL}-3$ & $\begin{array}{l}\text { Meets some of Navy's Occupational Safety and Health } \\
\text { (NAVOSH) Requirements per OPNAVINST } 5100.23 \\
\text { series. Support for management, coordination of } \\
\text { region-wide program, including but not limited to } \\
\text { management, inspections, evaluations, surveys, } \\
\text { education, training, instructions, mishap prevention, }\end{array}$ \\
\hline
\end{tabular}




\begin{tabular}{|c|c|c|}
\hline Sub-function & $\begin{array}{l}\text { Capability } \\
\text { level }\end{array}$ & Description \\
\hline & & 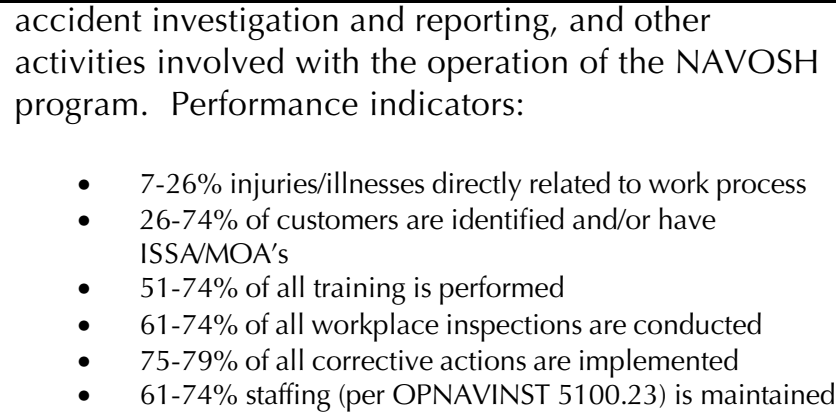 \\
\hline & $\mathrm{CL}-4$ & $\begin{array}{l}\text { Does not meet the Navy's Occupational Safety and } \\
\text { Health (NAVOSH) Requirements per OPNAVINST } \\
5100.23 \text { series. Support for management, coordination } \\
\text { of region-wide program, including but not limited to } \\
\text { management, inspections, evaluations, surveys, } \\
\text { education, training, instructions, mishap prevention, } \\
\text { accident investigation and reporting, and other } \\
\text { activities involved with the operation of the NAVOSH } \\
\text { program. Performance indicators: } \\
\text { - Greater than } 26 \% \text { injuries/illnesses directly related to } \\
\text { - Lork process } \\
\text { - Less than } 26 \% \text { of customers are identified and/or have } \\
\text { - Less than's } 51 \% \text { of all training is performed } \\
\text { - Less ths } 61 \% \text { of all workplace inspections are conducted } \\
\text { - Less than } 75 \% \text { of all corrective actions are implemented } \\
\text { maintained } 61 \% \text { staffing (per OPNAVINST 5100.23) is }\end{array}$ \\
\hline \multirow[t]{3}{*}{$\begin{array}{l}\text { Recreational/off-duty } \\
\text { safety }\end{array}$} & CL-1 & $\begin{array}{l}\text { Meet Navy's RODS Program Requirements per } \\
\text { OPNAVINST } 5100.25 \text { series. Support for management, } \\
\text { coordination of region-wide program, including but } \\
\text { not limited to management, inspections, evaluations, } \\
\text { surveys, education, training, instructions, and mishap } \\
\text { prevention. Performance indicators: } \\
\text { - } \quad 90-100 \% \text { ROD's training (military personnel) conducted } \\
\text { - } 95-100 \% \text { mishap investigations performed } \\
\text { - } 98-100 \% \text { ROD's inspections conducted }\end{array}$ \\
\hline & CL-2 & $\begin{array}{l}\text { Meet most of the Navy's RODS Program Requirements } \\
\text { per OPNAVINST } 5100.25 \text { series. Support for } \\
\text { management, coordination of region-wide program, } \\
\text { including but not limited to management, inspections, } \\
\text { evaluations, surveys, education, training, instructions, } \\
\text { and mishap prevention. Performance indicators: } \\
\text { - } \quad 75-89 \% \text { ROD's training (military personnel) conducted } \\
\text { - } \quad 80-94 \% \text { mishap investigations performed } \\
\text { - } 75-97 \% \text { ROD's inspections conducted }\end{array}$ \\
\hline & $\mathrm{CL}-3$ & $\begin{array}{l}\text { Meet some of the Navy's RODS Program Requirements } \\
\text { per OPNAVINST } 5100.25 \text { series. Support for }\end{array}$ \\
\hline
\end{tabular}




\begin{tabular}{|c|c|c|}
\hline Sub-function & $\begin{array}{c}\text { Capability } \\
\text { level }\end{array}$ & Description \\
\hline & & $\begin{array}{l}\text { management, coordination of region-wide program, } \\
\text { including but not limited to management, inspections, } \\
\text { evaluations, surveys, education, training, instructions, } \\
\text { and mishap prevention. Performance indicators: } \\
\text { - } \quad 51-75 \% \text { ROD's training (military personnel) conducted } \\
\text { - } \quad 75-79 \% \text { mishap investigations performed } \\
\text { - } 61-74 \% \text { ROD's inspections c onducted }\end{array}$ \\
\hline & $\mathrm{CL}-4$ & $\begin{array}{l}\text { Does not meet the Navy's RODS Program } \\
\text { Requirements per OPNAVINST } 5100.25 \text { series. } \\
\text { Support for management, coordination of region-wide } \\
\text { program, including but not limited to management, } \\
\text { inspections, evaluations, surveys, education, training, } \\
\text { instructions, and mishap prevention. Performance } \\
\text { indicators: } \\
\text { - Less than } 51 \% \text { ROD's training (military personnel) } \\
\text { - Londucted } \\
\text { - Less than } 75 \% \text { mishap investigations performed } \\
\text { Less than } 61 \% \text { ROD's inspections conducted }\end{array}$ \\
\hline \multirow[t]{3}{*}{ Traffic safety } & $C L-1$ & $\begin{array}{l}\text { Meet Navy's Traffic Safety Program Requirements per } \\
\text { OPNAVINST } 5100.12 \text { series. Support for management, } \\
\text { coordination of region-wide program, including but } \\
\text { not limited to management, inspections, evaluations, } \\
\text { surveys, education, training, instructions, and mishap } \\
\text { prevention. Performance indicators: } \\
\text { - } 90-100 \% \text { motorcycle, EVOC, and AAA training conducted } \\
\text { - } 90-100 \% \text { mishap investigations performed } \\
\text { - } 98-100 \% \text { GMV (auto/equipment) inspections conducted } \\
98-100 \% \text { roadway inspections conducted }\end{array}$ \\
\hline & $\mathrm{CL}-2$ & $\begin{array}{l}\text { Meet most of the Navy's Traffic Safety Program } \\
\text { Requirements per OPNAVINST } 5100.12 \text { series. } \\
\text { Support for management, coordination of region-wide } \\
\text { program, including but not limited to management, } \\
\text { inspections, evaluations, surveys, education, training, } \\
\text { instructions, and mishap prevention. Performance } \\
\text { indicators: } \\
\text { - } 75-89 \% \text { motorcycle, EVOC, and AAA training conducted } \\
\text { - } 80-89 \% \text { mishap investigations performed } \\
\text { - } 75-97 \% \text { GMV (auto/equipment) inspections conducted } \\
\text { 75-97\% roadway inspections conducted }\end{array}$ \\
\hline & $\mathrm{CL}-3$ & $\begin{array}{l}\text { Meet some of the Navy's Traffic Safety Program } \\
\text { Requirements per OPNAVINST } 5100.12 \text { series. } \\
\text { Support for management, coordination of region-wide } \\
\text { program, including but not limited to management, } \\
\text { inspections, evaluations, surveys, education, training, } \\
\text { instructions, and mishap prevention. Performance }\end{array}$ \\
\hline
\end{tabular}




\begin{tabular}{|c|c|c|}
\hline Sub-function & $\begin{array}{c}\text { Capability } \\
\text { level }\end{array}$ & Description \\
\hline & & 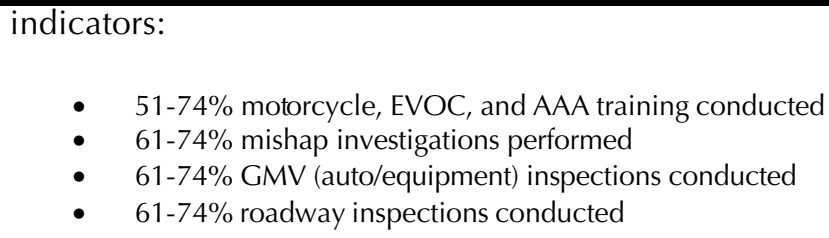 \\
\hline & $\mathrm{CL}-4$ & $\begin{array}{l}\text { Does not meet the Navy's Traffic Safety Program } \\
\text { Requirements per OPNAVINST } 5100.12 \text { series. } \\
\text { Support for management, coordination of region-wide } \\
\text { program, including but not limited to management, } \\
\text { inspections, evaluations, surveys, education, training, } \\
\text { instructions, and mishap prevention. Performance } \\
\text { indicators: } \\
\text { - Less than } 51 \% \text { motorcycle, EVOC, and AAA training } \\
\text { - Lenducted } \\
\text { - Less than } 60 \% \text { mishap investigations performed } \\
\text { - } 60 \% \text { GMV (auto/equipment) inspections } \\
\text { - Less than } 60 \% \text { of roadway inspections conducted }\end{array}$ \\
\hline
\end{tabular}

Source: [25]. 


\section{References}

[1] National Safety Council. Department of Defense Executive Assessment of Safety and Occupational Health Management Systems 6 Dec 2001

[2] The Honorable Donald Rumsfeld, Secretary of Defense. Reducing Preventable Accidents, 19 May 2003 (Memorandum for Secretaries of the Military Departments)

[3] Deputy Assistant Secretary of the Navy (Safety) Office of the Assistant Secretary of the Navy (Installations and Environment). Department of the Navy Safety Task Force, Final Report, submitted to the Secretary of the Navy. 29 Apr 2003

[4] Michael Bowes. An Analysis of DoN Mishap Rates, Mar 2004, (CNA Research Memorandum D0009828.A2)

[5] U.S. Department of Labor, Occupational Safety and Health Administration. Voluntary Protection Program. On the Internet at www.osha.gov/dcsp/vpp/index.html. Accessed on 8 Jul 2004

[6] SECNAV Safety Policy. Accessed online at http://safetycenter.navy.mil/articles/secnavpolicy.htm

[7] Department of Labor, Occupational Safety and Health Adminstration. Revisions to the Voluntary Protection Programs to Provide Safe and Healthful Working Conditions. Federal Register. 65(142): 45649-45663

[8] J.C. Manzella "Measuring Safety Performance to Achieve LongTerm Improvement.” Professional Safety. Sep 1999: 33-36

[9] T.S. Ingalls "Using Scorecards to Measure Safety Performance. Professional Safety. Dec 1999: 23-28

[10] R.S. Stricoff "Safety Performance Measurement: Identifying Prospective Indicators with High Validity." Professional Safety. Jan 2000: 36-39

[11] J. Toellner "Improving Safety \& Health Performance: Identifying and Measuring Leading Indicators." Professional Safety." Sep 2001: $42-47$

[12] E.J. Sheehy "Effective Safety Incentives." Professional Safety. Feb 2004: 40-48 
[13] William B. Boning Metrics for N80: Considerations in Selection and Application to the Programming Process, Apr 2002 (CNA Research Memorandum D5650.A2)

[14] On the Internet at www.alcoa.com/global/en/environment/goals.asp Accessed on 8 Jul 2004.

[15] Naval Safety Center. 2002-2005 Strategic Plan.

[16] Memorandum for the Secretary of the Navy, Chief of Naval Obligations, and Commandant of the Marine Corps to All Hands. DON Objectives for 2004. 16 Jan 2004. On the Internet at http://www.safetycenter.navy.mil/MishapReduction/files/objectives0 4.pdf accessed on 3 May 2004

[17] Administrative Message ALNAV 057/03 from SECNAV Washington DC. Reducing Mishaps. 15 Jul 2003.

[18] Message from COMSUBPAC Pearly Harbor Hawaii to SUBPAC. Subj: CNO Safety Initiative. R 030103Z Jun 04 PSN 564907H31

[19] R. Flin, K. Mearns, P. O'Connor, and R. Bryden. "Measuring Safety Climate: Identifying the Common Features." Safety Science. 2000(34): 177-192.

[20] On the Internet at www.safe tycenter.navy.mil/statistics/definitions.htm

[21] M. Behm, A. Veltri, and I.K. Kleinsorge. "The Cost of Safety." Professional Safety 2004(Apr): 22-29.

[22] R.J. Coble et al. Construction Safety and Health Management, Upper Saddle River, NJ: Prentice-Hall Inc, 2000.

[23] FY04 Shore Safety OMN Budget Extract, Capability-Based Budgeting Data Collection, 1 Dec 2003 (http://www.navy-imclearinghouse.net/cbb04)

[24] FY05 Shore Safety OMN Budget Extract, Capability-Based Budgeting Data Collection, 22 Apr 2004 (http://www.navy-imclearinghouse.net/cbb05)

[25] Safety IPT Revised Readiness Definitions, Base Operating Services Integrated Process Teams, 22 Aug 2001 (http://www.navy-imclearinghouse.net/BOSIPTs/Safety) 
[26] Safety Function Capability Level Descriptors \& Risks, CapabilityBased Budgeting Data Collection, 22 Apr 2004 (http://www.navyim-clearinghouse.net/cbb05) 


\section{List of figures}

Figure 1. Halliburton's Health, Safety and Environment ........ 11 Management Architecture

Figure 2. Cost of quality (safety) model ..................... 25 


\section{List of tables}

Table 1. Selected industry and government leaders _. . 8 in occupational health and safety

Table 2. Key elements of industry leaders' safety models . . 9

Table 3. Demonstrating management leadership and . . 15 employee involvement

Table 4. Examples of downstream and upstream safety . . . 17 measures

Table 5. Mishap definitions by class _ . . . . . 20

Table 6 Identified Navy Safety Funding, budgeted . . . 27 FY 2004(a), projected FY 2005

Table 7. Naval Safety Center current and estimated . . 28 future funding, 2004-2006

Table 8. Naval Safety Center personnel authorizations. . . 29

Table 9. FY 2004 Navy capability-based budget. . . . . . 30 allocation for ashore safety

Table 10. FY 2005 Navy capability-based budget. . . . . 30 allocation for ashore safety

Table 11. Summary of ashore safety readiness condition . . 31 classifications

Table 12. Summary of Navy ashore safety capability- . . . . 32 Level 3 Descriptions

Table 13. Summary of Navy ashore safety capability- . . . 35 level descriptions 


\section{Distribution list CRM D0010565.A2/Final}

Office of the Assistant Secretary of the Navy (RDA) (5 copies)

Deputy Assistant Secretary of the Navy (Safety) (5 copies)

Commander, Naval Safety Center

Director, Safety Division, Headquarters Marine Corps

Office of the Assistant Secretary of the Navy (Installation and Environment)

ATTN: Roger Normand

Commander, NAVAIRSYSCOM

Commander, NAVSEASYSCOM,

Commander, MARCORSYSCOM

Commander, Air Warfare (N78)

ATTN: CDR Jay Adelman

Paul Westphal (N783C1)

Commander, Surface Warfare (N76)

Head, Occupational Health and Safety Branch, Navy Bureau of Medicine and Surgery

ATTN: CAPT Eurgene Godwin (M3F4)

CDR Robin Wilkening (M3F4D)

Robert Colton (M3F42)

Carla Treadwell (M3F422)

Deputy, Special Assistant for Safety Matters (N09FB)

ATTN: CAPT Noulis

Joy Erdman 


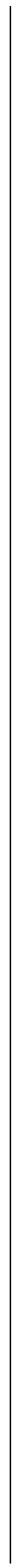





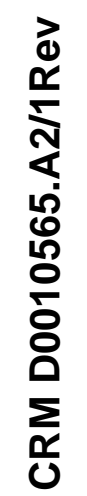

CNA 